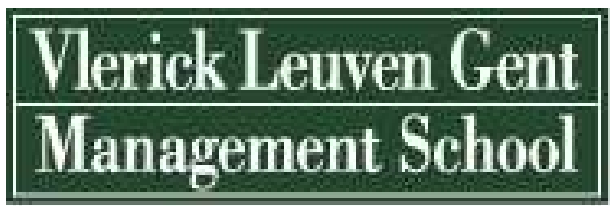

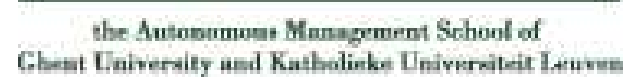

Vlerick Leuven Gent Working Paper Series 2009/10

THE VALUE OF ANALYSTS' RECOMMENDATIONS AND

THE ORGANIZATION OF FINANCIAL RESEARCH

\author{
CAROLINA SALVA \\ Carolina.Salva@vlerick.be \\ FREDERIC SONNEY \\ Frederic.Sonney@vlerick.be
}




\title{
THE VALUE OF ANALYSTS’ RECOMMENDATIONS AND
}

\section{THE ORGANIZATION OF FINANCIAL RESEARCH}

\author{
CAROLINA SALVA \\ Carolina.Salva@vlerick.be \\ FREDERIC SONNEY \\ Frederic.Sonney@vlerick.be
}

We are grateful to Kevin Aretz, François Degeorge, Michel Dubois, Pascal Dumontier, René Stulz and seminar participants at the European Finance Association annual meetings 2006, the Financial Management Association annual meetings 2006 and Bern Universität 2007 for helpful comments. We are also grateful to Thomson Financial for access to their Institutional Brokers Estimate System (I/B/E/S) Databases. Financial support by the Swiss National Science Foundation (SNSF), grant No. 100012-105432/1, is also gratefully acknowledged. The SNSF is acting on a mandate issued by the Swiss Federal Government and promotes independent research.

\section{Contact:}

Carolina Salva

Vlerick Leuven Gent Management School

Tel: +3216248821

Fax: +32 16248800

Email: Carolina.Salva@vlerick.be 


\begin{abstract}
Brokerage houses usually organize their research activities by country or economic sector. We evaluate which research structure provides most value to investors. To do so, we study the relative information content of recommendations issued by country-specialized analysts and sector-specialized analysts. Our findings show that the former issue more valuable recommendations. The strength of country-specific commonalities explains at least part of the better performance of country-specialized financial analysts. Surprisingly, although analysts' geographic location has been shown in the literature to be a determinant of earnings forecast accuracy, it is not a source of a comparative advantage when it comes to stock recommendations.

JEL Classification: G1, G29, D82
\end{abstract}

Keywords: financial analysts, stock recommendations, country and sector factors, geography 


\section{INTRODUCTION}

Brokerage houses usually organize their research activities by country or economic sector. The units of production are financial analysts who dedicate their time and effort to issuing earnings forecasts and recommendations for the set of firms they follow. There are probably different forces that shape how analysts' research is structured such as commonalities across firms, the information environment, customer needs, and cost considerations. No matter what drives analyst specialization, large amounts of money are invested every day on the basis of analysts' recommendations. This makes it important to understand which organization structure gives investors most value.

The information environment and the existence of commonalities across firms are significant determinants of the structure and quality of financial research. ${ }^{1}$ The quality of analysts' recommendations is influenced by the availability and quality of information and by the models they use to interpret this information. In addition, information complementarities can facilitate the process of analyzing firms and contribute to a better understanding of firms' economics. They provide a rationale for why analysts tend to specialize and choose portfolios of firms that share certain commonalities. According to Kini et al. (2003), analysts tend to cover single-country portfolios in countries where national influences are strong, and specialize in firms that belong to a single economic sector in industries where common economic forces are prominent. As they argue, this is consistent with the objective of taking advantage of economies of scale in information acquisition and production to produce highquality research.

The importance of adapting financial research to customer needs is emphasized in Rubino (2003). ${ }^{2}$ Customer needs refers to the way fund managers structure their investment process. Investors who believe that financial markets are segmented try to profit from international diversification. They mostly need country-specific research. For instance, they are willing to know the future top-performing firms within each country. Investors who, on the contrary, are convinced that financial markets are highly integrated rely on sector diversification. For that reason, they tend to value global sector-based approaches. Sector-bysector analysis is then more appropriate to the specific needs of these fund managers.

\footnotetext{
${ }^{1}$ Berger et al. (2003), Petersen and Rajan (2001), and Stein (2002) focus on the importance of the information environment in the organization of financial intermediaries.

2 John Rubino, "The New Global Industry Analysis", CFA Magazine, July-August 2003 (quoted in Kini et al. (2003)).
} 
The forces and constraints that shape how financial research is organized may affect brokerage houses in different ways. In this paper, we evaluate which research structure provides most value to investors. To this end, we explore whether stock recommendations issued by country-specialized analysts contain more information than recommendations issued by sector-specialized analysts, or vice versa. ${ }^{3} \mathrm{We}$ focus on financial research performed on European equities, for which both country-based research and sector-based research exist. ${ }^{4}$

Our findings show that stock recommendations issued by country specialists contain more information than those released by sector specialists. When the recommendation is released, the stock price reaction is stronger for recommendations issued by country specialists. Furthermore, there is additional information provided by country specialists that is slowly incorporated into prices, with a drift lasting up to 20 trading days. Conversely, there is no drift after recommendations issued by sector specialists. We interpret this delayed price reaction for country specialists as evidence of greater information content since it is related to the type of analyst, not the type of firm. Risk shifting, for example, is not a plausible explanation, as for any given firm the drift is stronger after a recommendation issued by a country specialist than after one issued by a sector specialist.

We further explore whether our findings stem from information complementarities and economies of scale in gathering and processing information. More specifically, we evaluate different sources that could explain the informational advantage of country specialists, such as country factors, governance regimes, financial disclosure environments and geographic proximity to the firm. Commonalities across firms may stem from a shared a country of domicile. Firms within a country share the same reporting and governance systems and are subject to similar economic forces. High-quality institutional structures (i.e. highquality disclosure and good governance, which translates into more transparency) have a positive impact on the information environment and may require less country-specific knowledge. Also, with a better information environment, the role of geographic and cultural proximity may be less important.

\footnotetext{
${ }^{3}$ From now on, we interchangeably call country-specialized analysts "country specialists" and sector-specialized analysts "sector specialists".

${ }^{4}$ Financial research on US equities is mostly organized along sector lines and for Asian equities country-based research is most preferred. See Reuters Institutional Investor Survey, Institutional Investor Research Group (2002) also mentioned in Kini et al. 2003. To the contrary, research on European firms, even though biased towards country-based structures, is performed by both country and sector specialists. Approximately 30\%, respectively $70 \%$, of the 6587 analysts considered in our sample where sector, respectively country, specialists.
} 
For these reasons, we explore whether the information advantage of country specialists is stronger in countries with lower-quality institutional structures. Our results suggest that the disclosure environment and the legal protection for shareholders partly explain the country specialists' advantage.

Country specialists' advantage may result as well from a geographic advantage. These analysts are on average based closer to the firms they follow and may therefore have better access to private information. They are also generally based within the same country as the firms they follow, thus increasing cultural and institutional proximity, although neither of these dimensions of proximity seems to be a source of a comparative advantage. Our results indicate that neither being close or being located within the same country as the firm is an important determinant of the additional information contained in stock recommendations issued by country-specialized analysts.

We then investigate whether country specialists draw their comparative advantage from recommendations issued for firms headquartered in countries with strong common economic forces. Results show that part of the additional information conveyed by country specialists' stock recommendations can be explained by this factor. Country-specific variables therefore appear to be important determinants. Sector specialists, who may need to summarize these variables when valuing firms from different locations, are at a disadvantage, as they may lose valuable of information.

Even though we perform a battery of tests to check the robustness of our results, we are aware of potential limitations of this study. Some of the variables considered as potential explanations for the differences in the relative information content of recommendations issued by country and sector specialists are quite highly correlated. This makes it a hard task to disentangle the individual effect. For instance, countries with low accounting standards are likely also to provide low shareholder protection. They are also likely to be the smallest national markets in the sample. Therefore, our tests should not be viewed as an unequivocal explanation of the comparative advantage of country specialists. Instead, our results are more likely to indicate under which conditions country specialists bring more information than their sector peers. All of these conditions may not be mutually exclusive.

The paper is organized as follows. Section 2 presents a brief review of the extant literature on the value of stock recommendations. In section 3, we discuss the objectives and constraints that shape brokerage houses' organization of research on European equities. Section 4 introduces the data and the methodology. In section 5, we focus on financial analysts. 
We analyze their portfolio characteristics, how they tend to specialize, and whether there is an informational advantage linked to specialization. Section 6 is devoted to explanations of the comparative advantage that country specialists seem to have over sector specialists. We conclude in section 7.

\section{THE VALUE OF STOCK RECOMMENDATIONS AND ITS DETERMINANTS}

Stock recommendations constitute a final output of analyst research and reflect analysts' overall opinion about the value of stocks in relation to their market price. Elton, Gruber, and Grossman (1986) highlight the unequivocal piece of information constituted by analyst recommendations. They write: "Stock recommendations clearly and unambiguously indicate whether financial analysts consider any given security as under- or over-valued." In contrast, earnings forecasts represent an intermediate number contributing to stock recommendations. As Schipper (1991) emphasizes, analysts' earnings forecasts are just one ingredient used to evaluate the investment potential of a stock. Thus, stock recommendations may incorporate further country- and sector-specific analysis and judgments beyond what is included in one-year-ahead earnings forecasts. For that, we focus on analysts' stock recommendations. ${ }^{5}$

Various studies show that analysts' recommendations convey valuable information to investors. Womack (1996), Francis and Soffer (1997), Ivkovic and Jegadeesh (2004), and Asquith et al. (2005), among others, document a positive relationship between recommendation upgrades and downgrades and stock prices. Those studies show that significant price reactions occur both when recommendations are released and in the months after. Womack (1996) finds that the drift appears to last up to six months after recommendation downgrades, whereas it is shorter-lived when stocks are upgraded. All of these studies focus on recommendations issued on U.S. equities. A notable exception is Jegadeesh and Kim (2006), who extend the investigation to the G7 countries. They report that, although abnormal returns are highest in the U.S., recommendation changes significantly affect prices in all G7 countries. They also find that prices continue to drift in the direction of the recommendation change over the following two to six months in all of the countries.

\footnotetext{
${ }^{5}$ See also e.g. Asquith et al. (2005). They explore additional information pieces contained in financial analysts' reports, such as target price revisions, and the strength of the quantitative and qualitative arguments.
} 
Beyond that, there is limited evidence on the value of stock recommendations in Europe.

Despite the importance that both academics and practitioners attach to the information content of stock recommendations, there is limited evidence on what factors determine the value of those recommendations. Stickel (1995) is among the few authors who analyze the short- and long-term price performance of analysts' recommendations and identifies some contributing factors. He shows that the stock price reaction is positively related to the strength of the recommendation, the size of the brokerage house issuing the recommendation, and the analyst reputation, and is negatively related to the size of the firm. Asquith et al. (2005) report a similar result and show that the price reaction around the release of recommendations is negatively related to the number of analysts following the firm. Ivkovic and Jegadeesh (2004) show that the stock price reaction is weaker when recommendations are released immediately after earnings announcement dates. They conclude that financial analysts add more value by gathering information than by interpreting it. Boni and Womack (2004) support this view, as they show that price reactions to analyst recommendations generally increase with time from the last scheduled earnings announcement. Loh and Mian (2006) results are consistent with the notion that the value of analysts' recommendations is founded in economic rationale and not on other ad hoc firm characteristics. ${ }^{6}$ The common theme of the studies cited above is that stock recommendations are valuable because analysts have superior information than the market as a result of their gathering and interpreting skills.

Other studies focus on the analysis of the information content of earnings forecast. These studies reveal additional variables that can explain the differential information content of analysts' output. Some of these variables are related to geographic factors. In the context of European markets, Orpurt (2004) shows that financial analysts located in the same country as the firms they follow issue on average more accurate earnings forecasts than analysts based abroad. Enlarging the investigation to a sample of 32 countries, Bae et al. (2005) confirms this finding. Malloy (2005) examines another geographic dimension: that of physical distance. Building on the work by Coval and Moskowitz (2001) on fund managers, Malloy (2005) computes the "fly of bird" distance between analysts and the firms they cover. He reports that proximate analysts strongly outperform analysts located farther away.

\footnotetext{
${ }^{6}$ A confronting view is that offered by Jegadeesh et al. (2004), Cornell (2001), and Bradshaw (2004) who argue that the market reaction to analysts' recommendations is related to heuristic firm characteristics rather than founded in economic analysis or stock picking ability.
} 
Physical proximity, as well as being located within the same country as firms' headquarters, may therefore also play an important role in the value that analysts deliver to investors.

We further hypothesize that the composition of analysts' portfolios and particularly analysts' specialization may be important in determining the relative level of information contained in stock recommendations. In the next section, we discuss potential explanations that could support this hypothesis.

\section{THE ORGANIZATION OF RESEARCH DEPARTMENTS: COUNTRY VERSUS SECTOR SPECIALIZATION}

The quality of analysts' recommendations is influenced by the availability and quality of information and by the models or skills used to process this information. These are broadly the two sources of value in analysts' recommendations. Ivkovic and Jegadeesh (2004) show that the dominant source of analysts' value lies in the quality of information rather than its interpretation.

To exploit economies of scale in gathering information, Kini et al. (2005) show that analysts tend to specialize and choose portfolios of firms that share certain commonalities. Commonalities across firms may stem from sector- or country-specific factors. If analysts think that firms' earnings and value are largely driven by common factors within an economic sector of activity, they may choose to follow only companies within a sector. Similarly, country specialists will tend to follow only firms located in the same country and for which national forces may be the most significant driver of future earnings.

The organization of research may also be shaped by other forces and constraints. Despite the predictions of Kini et al. (2005), when we look at analysts' portfolios, we find that firms are often followed by both country and sector specialists. That is, there are sector specialists following firms that have important country-factor commonalities and vice versa. It is probable that when choosing their portfolios, analysts' weigh forces and constraints beyond economies of scale in gathering and interpreting information.

If some analysts' portfolios benefit from the information environment more than others, it is plausible that the quality of analysts' forecasts and the value they deliver to investors differ. 
Actually, we expect that recommendations issued by analysts whose portfolios benefit most from the existence of commonalities across firms are those that are more informative about the true value of the firm. For example, if the earnings of a given firm are driven largely by country economic forces, we would expect country specialists to benefit from economies of scale in using country-specific information and to issue superior forecasts and recommendations. In fact, Sonney (2005) shows that country specialists issue on average more accurate earnings forecasts and finds that geographical proximity constitutes a significant determinant of this superior performance. Yet better accuracy need not necessarily translate into more informative recommendations. ${ }^{7}$ In our example, sector specialists could be at a disadvantage in terms of economies of scale in gathering and using information; however, they could benefit from using a valuation model that captures well the economics of the sector that they follow. Indeed, Demirakos et al. (2005) remark that analysts tailor their valuation methodology to the industry in which the firms operate. ${ }^{8}$ It is also possible that less accurate earnings forecasts translate into more informative stock recommendations because recommendations may include information in addition to that attached to forecasts. For example, analysts provide a justification for their recommendations, but not for their forecasts. Also, focusing on recommendations allows us to evaluate whether and how investors recognize the informational advantage that analysts may have.

It is well documented that complexity affects the accuracy of analysts' earnings forecasts because processing limitations and shortages of time cause some information to be excluded or simplified. So, it may well be that it also has implications for the value of stock recommendations; see Plumlee (2003), Brown (1987), Haw et al. (1994), Lang and Lundhom (1996), Duru and Reeb (2002), Clement (1999), Malloy (2002), Clement et al. (2003). An important source of complexity for country specialists lies in the fact that they follow firms in different sectors. Therefore, there may be a limit to the sector-specific information they can process. For sector analysts, complexity arises from following firms from different countries. They need to obtain country-specific information for each country represented in their portfolio. Before using this information, they need to standardize it across firms.

\footnotetext{
${ }^{7}$ Loh and Mian (2006) document a positive association between the value of recommendations and the quality of forecasts for U.S. equities. Relying on their findings, they argue that stock picking ability is founded on economic rationale and not on ad hoc firm-specific characteristics. See Jegadeesh et al. (2004), Cornell (2001) and Bradshaw (2004).

${ }^{8}$ The analysis of strategic issues and R\&D projects is the critical part of the valuation process in the pharmaceuticals industry, whereas the brand strength, and innovative skills and competence in technology are the center of attention respectively in the beverages and electronics industries.
} 
This standardization may lead to a loss of information value that may be larger when country-specific factors are more important. If country-specific information appears to be more important to assess the investment potential of a firm than sector-specific information, then sector specialists may be at a disadvantage.

Several studies provide evidence that country factors are important. These studies stress that there are still numerous divergences among national markets. Since the mid-1990s and the work of Heston and Rouwenhorst (1994, 1995), much attention has been devoted to the relative impact of industry and country factors on stock returns. Heston and Rouwenhorst (1994, 1995), Beckers et al. (1996), and Griffin and Karolyi (1998), among many others, conclude that country factors are more important determinants of stock returns than sector factors. More recently, Cavaglia et al. (2000) and Baca et al. (2000) reveal a growing influence of industry factors. Moreover, their results lead to the impression that sector factors may even have become more important than country factors at the end of the 1990s. However, as is apparent in the work by Adjaouté and Danthine (2003), the relative influence of country and sector factors in stock returns appears to follow cycles. The Cavaglia et al. (2000) and Baca et al. (2000) studies would very likely have returned the same results if they had been carried out in the mid-1970s. Our reading of this literature is that country-specific factors still exist and may even have strong impacts on firms' earnings and stock prices. Thus, these studies suggest that country commonalities across firms are important; country specialists therefore, could have an advantage over sector specialists.

Despite of the overwhelming evidence that country-specific factors may still play an important role, professional circles currently seem to favor a global-sector-based approach. Focusing on international fund managers, Galati and Tsatsaronis (2001) report the results of a survey conducted on behalf of Merrill Lynch that shows that in 2000, 75 percent of surveyed fund managers answered that sector diversification was their primary objective, and only 10 percent gave priority to the international diversification approach. If investor needs are important in shaping analysts' portfolios, their preferences may tend to influence the structure of financial research. 


\section{DATA AND EXPERIMENT DESIGN}

\subsection{Data}

The construction of our sample starts with all recommendations on European firms issued during the period 1994-2003, regardless of the location of the analysts who issue the recommendation. We focus on the 15 major European markets, namely, Austria, Belgium, Denmark, Finland, France, Germany, Ireland, Italy, the Netherlands, Norway, Portugal, Spain, Sweden, Switzerland, and the UK. As we have already discussed, our choice to restrict the analysis to European markets stems from the fact that the organization of financial research departments along country or sector lines is mainly a European phenomenon. Therefore, our focus on these markets provides us with a large cross-section of country- and sector-specialized analysts. ${ }^{9}$

Financial analysts' stock recommendations are extracted from the I/B/E/S International and US Recommendation History databases. The I/B/E/S Identification File is also used to obtain the country of origin of each firm, as well as the industry sector in which each firm operates. Eleven sectors are defined: finance, health care, consumer nondurables, consumer services, consumer durables, energy, transportation, technology, basic industries, capital goods, and public utilities. We exclude from the sample firms for which I/B/E/S does not provide us with a country, an industry, or the name of the analyst who issues the recommendation.

Market data such as stock prices, dividends, risk-free interest rates, and firms' market capitalization are taken from the Thomson Financial Datastream database. From this database, we also obtain the market index SP350 Europe (euro currency) that we use as a benchmark. The availability of market data for each firm imposes additional restrictions on our final sample, which includes only firms with available price and recommendations data in both the $\mathrm{I} / \mathrm{B} / \mathrm{E} / \mathrm{S}$ and Datastream databases.

Other sources are used to obtain further relevant data and control variables that we introduce in following sections. The Worldscope database provides us with data on the geographic locations of firms' headquarters.

\footnotetext{
${ }^{9}$ In general, analysts following Japanese firms are country specialists, whereas research on US firms tends to be structured according to sectors.
} 
Financial analysts' addresses are found in different editions—-from 1994 to 2003 — of Nelson Information's Directory of Investment Research. Latitude and longitude data needed to compute the distance between analysts and the firms they follow are extracted manually from the Website www.heavens-above.com. Finally, we obtain the country-specific variables relating to accounting standards and shareholder protection used by La Porta et al. (1998) from the Center for International Financial Analysis and Research and.

\subsection{Analysts' Specialization}

As a next step, we classify all analysts according to their specialization. To this end, we compute the Herfindahl Index (HI), a concentration ratio that is generally used as an indicator of the degree of competition in an industry. This ratio allows us to classify as sector (country) specialists those analysts that concentrate on firms within the same sector or industry (country). It is possible that sector (country) specialists also issue recommendations for firms that belong to other sectors (countries) but this activity is marginal. The advantage of using this measure to classify analysts according to their specialization is that it is based on concentration. For example, it allows us to classify as a sector specialist an analyst who follows ten firms in the same sector and one firm in a different sector. An alternative classification could consist of defining as sector (country) specialists only those analysts following firms in a single sector (country). But this measure would be much more restrictive, and would not consider the analyst in our example a sector specialist.

For each analyst, we compute both a sector and a country HI as follows

$$
\begin{gathered}
H I_{a, y}^{\text {Country }}=\sum_{c=1}^{C} \alpha_{c}^{2} \\
H I_{a, y}^{\text {Sector }}=\sum_{s=1}^{S} \alpha_{s}^{2}
\end{gathered}
$$

where $\alpha_{c}=N_{c, a, y} / N_{a, y}$ and $\alpha_{s}=N_{s, a, y} / N_{a, y} \cdot N_{c, a, y}\left(N_{s, a, y}\right)$ is the number of firms in country c (sector s) for which analyst $a$ issued forecasts over fiscal year $y . N_{a, y}$ is the total number of firms followed by analyst $a$ over fiscal year $y$.

A country HI takes a value of 1 (i.e., its maximum value) when the analyst follows firms that are all headquartered within a single country. Similarly, a sector HI takes value of 1 when the analyst follows firms that are active in one sector. 
Analysts who also follow few firms in other countries (sectors), but who devote most of their attention to firms within a single country (sector) will have a country (sector) HI close to one. HI values go towards zero as analysts' portfolio diversification increases.

Each analyst is classified as a country specialist if her or his country HI is larger than 0.90 and her or his sector HI is smaller than 0.90. Each analyst is classified as a sector specialist if her or his sector HI is larger than 0.90 and her or his country HI is smaller than $0.90 .{ }^{10}$ For the purpose of our analysis, we take only analysts who are either country or sector specialists. We drop analysts who follow many countries and many sectors and analysts who mainly follow only one sector in one country.

\subsection{Event Study}

To evaluate the information content of analysts' recommendations, we compute abnormal returns around the day that an analyst issues a recommendation. For that, we follow standard event-study methodology as in Brown and Warner (1985). The event day is the day the recommendation is issued as reported by $\mathrm{I} / \mathrm{B} / \mathrm{E} / \mathrm{S}$. Following existing literature, we define the estimation period as the interval $[-200,-11]$ with respect to the announcement date. Abnormal returns are the prediction errors from the one-factor OLS market model calculated over the estimation period, where the explanatory factor is the market index SP350 Europe. Both stock returns and the market index are log-differences computed in euros.

Our sample includes some small firms that are thinly traded. Infrequent trading can be problematic, as it can induce autocorrelation in stock returns. To appropriately account for that possibility, we follow the Maynes and Rumsey (1993) "trade-to-trade" approach. They show that the use of "trade-to-trade" returns leads to correct estimations for all levels of trading frequency.

\footnotetext{
${ }^{10}$ The choice of 0.90 as a threshold is somewhat arbitrary. Though, a closer look at the data suggests that it accurately depicts analysts' specialization. Results remain unchanged with thresholds of $0.80,0.85$, and 1 .
} 
The trade-to-trade approach uses multiperiod returns computed as

$$
R_{i, n_{t}}=\ln \left(\frac{P_{i, t}}{P_{i, t-n_{t}}}\right)
$$

where $n_{t}$ is defined as the length of the non-trading interval ending at date $t . P_{i, n_{t}}$ is the last quoted price before the non-trading interval, in euros. The abnormal return is computed as the difference between the actual return and the expected return over the event window as follows:

$$
A R_{i, n_{t}}=R_{i, n_{t}}-E\left[R_{i, n_{t}}\right]=R_{i, n_{t}}-\left[\hat{\alpha}_{i} n_{t}-\hat{\beta}_{i} R_{m, n_{t}}\right]
$$

where $R_{m, n_{t}}$ is the market index return over the non-trading period that matches the stock return. $\alpha_{i, n_{t}}$ and $\beta$ are the WLS coefficients calculated over the estimation window. The errors from the "trade-to-trade" adjusted one-factor model are heteroskedastic with variance $n_{t} \sigma_{i}^{2}$. To correct for heteroskedasticity, the data are divided by the square root of $n_{t}$ (weights). ${ }^{11}$

Once we have obtained abnormal returns we cumulate them over the following intervals $[-1,+1],[+2,+20]$ and $[+21,+60]$, and we obtain CABNRET, CABNRET2O and CABNRET60 correspondingly. CABNRET allows us to evaluate the market reaction at the time when stock recommendations are issued. The other measures provide us with some insight into whether a price drift follows the date when the recommendation is issued. We find that the mean CABNRET is $0,31 \%$ for upgrades and $-0,38 \%$ for downgrades. This is much lower than cumulative returns reported for US firms but it is in line with results in Dubois and Dumontier (2008) and Jegadeesh and Kim (2006) who provide estimations for countries such as UK, France, Germany and Italy. Also consistent with these studies, for the period $[-1,+60]$, the mean cumulative abnormal return is $0,66 \%$ for upgrades and $-0,89 \%$ for downgrades.

\footnotetext{
${ }^{11}$ Alternatively, we also compute size and mean adjusted abnormal returns (unreported) and re-estimate model (1) and (2) below. The results are qualitatively similar to the ones reported in the paper.
} 


\subsection{Cross-Sectional Regression Tests}

Here, we introduce the approach that we follow to examine the relation between the price reaction, recommendations, and the structure of analysts' portfolios. We consider that the price reaction is related to the direction and the magnitude of the recommendation change. For that, we define SURP as in Jegadeesh and Kim (2006) or Clement and Tse (2005), a variable indicating the surprise - or difference - between the newly issued recommendation and the last recommendation by the same analyst on the same firm. ${ }^{12}$ In some instances, analysts discontinue their coverage of a firm for quite long periods. Given that, we include a recommendation in the final sample only if there is a previous recommendation by the same analyst on the same firm that is no more than 360 days old. Although brokers usually follow a home-made classification for stock recommendations, I/B/E/S translates recommendations in a unique five-scale grouping. The values 1 to 5 are respectively assigned to Strong Buy, Buy, Hold, Sell, and Strong Sell recommendations. As in previous studies, we reverse the scale used by $\mathrm{I} / \mathrm{B} / \mathrm{E} / \mathrm{S}$ to have positive (negative) values for upgrades (downgrades). SURP can therefore take discrete values that range from -4 to +4 . Our baseline regression model is the following:

$$
C A B N R E T_{\left[t_{0} ; i_{1}\right]}=\alpha+\beta \cdot S U R P+\gamma \cdot \text { Controls }+\varepsilon
$$

If recommendation changes convey information that affects stock prices, we expect the slope coefficient $\beta$ to be significantly positive. To test whether country-specialized analysts issue more informative stock recommendations, we expand model (1) and estimate the following equation:

\footnotetext{
${ }^{12}$ Alternatively, we define SURP as the difference between the current recommendation and its consensus where the consensus is computed as the average of all outstanding analyst recommendations issued over the previous year (see Dubois and Dumontier (2008)). This alternative definition of the surprise does not have any bearing on our conclusions.
} 


$$
C A B N R E T_{\left[t_{0} ; t_{1}\right]}=\alpha+\beta_{c} \cdot S U R P \cdot C O U N T R Y S P+\beta_{s} \cdot S U R P \cdot S E C T O R S P+\gamma \cdot \text { Controls }+\varepsilon
$$

where COUNTRYSP equals 1 if the analyst is a country specialist and 0 otherwise, and SECTORSP equals 1 if the analyst is a sector specialist and 0 otherwise. This specification allows us to test whether there is any difference in the information that country and sector specialists convey to the market. If there is no information advantage of one group over the other then we expect $\beta_{c}=\beta_{s}$. However, if one group has an advantage in gathering and processing information then the coefficient will be larger for the group that conveys more information to the market.

Empirical studies on stock recommendations motivate the use of several control variables. Thus we define the following characteristics: broker size, number of analysts covering the firm, days in relation to the earning announcement date and to previously issued recommendations for the same firm and firm market capitalization. The first three are constructed from the information made available by I/B/E/S. Firms' market capitalization is computed with data taken from Datastream.

Stickel (1995) argues that large brokerage houses have the resources to disseminate stock recommendations more efficiently to investors. Also, in large brokerage houses, analysts have more resources to gather and process information. It is therefore likely that their results may be of higher quality and as a consequence have a stronger impact on stock prices. Stickel (1995) indeed shows that the stock price reaction to recommendation releases is larger when recommendations are issued by analysts working for large brokerage houses. To control for this effect, we rank brokerage firms based on the number of analysts employed over a given year. Then we define BRKSIZE, a dummy variable that equals one if the broker belongs to the highest size deciles and zero otherwise.

Large firms are in general followed more actively by financial market participants. Therefore, the marginal information brought to the market by recommendations issued on large firms and followed by a large number of analysts is likely to be of less investment value than the recommendations issued on less frequently investigated firms. A measure that is commonly used as a surrogate for the firm's information environment is the number of analysts following the firm. Thus for each recommendation, we define NUMANA as the number of analysts who issued at least one recommendation on the firm over the 360 days preceding the recommendation release. The firms' market capitalization $M V$ is another measure that is commonly used, see Stickel (1995). 
In fact, as is noted by Asquith et al. (2005), both $M V$ and NUMANA serve as proxies for the firm-specific information environment that less actively followed firms may have compared with more widely followed firms. Since these two measures are correlated we only consider NUMANA in our estimations; however, we note that our results remain virtually the same if we substitute NUMANA by $M V$.

Ivkovic and Jegadeesh (2004) show how the price reaction depends on whether the recommendation precedes or follows the earnings announcement date and also on how close the recommendation is to the earnings announcement date; see also Boni and Womack (2004). We include three dummy variables to account for the differential information content of recommendations issued before and after earnings announcements. First, PAGE (i.e., precedes an earnings announcement) equals 1 if the recommendation is issued within the 10 days preceding an earnings announcement date and zero otherwise. FAGE (i.e., follows an earnings announcement) equals 1 if the recommendation is issued within the 10 days following an earnings announcement date. Finally, the variable CAGE (i.e., contemporaneous with an earnings announcement) is equal to 1 if the recommendation is released on the same day as the earnings announcement. The use of these three control variables has a double objective. They are aimed at controlling for the varying level of information content of recommendations reported by Ivkovic and Jegadeesh (2004) and Boni and Womack (2004). They also have the objective of avoiding the possibly confounding effect of earnings announcements and recommendation releases that occur within the same couple of days.

Intuitively, the value of recommendations should also depend on whether they are issued right after other recommendations for the same firm or on whether they are lead recommendations. Cooper, Day and Lewis (2001) suggest that the timeliness of the recommendation can be relevant in explaining abnormal returns. To account for this possibility, we follow Dubois and Dumontier (2008) and compute TIMELINESS as the number of recommendations issued during the previous month for the same firm. The larger is TIMELINESS, the lower the information content of a new recommendation and the lower its price impact. In addition, to avoid confounding effects we discard all recommendations that are issued simultaneously in the window $[-1,1]$ by both country and sector specialists.

The explanatory variables that we use as controls are expected to have reverse signs for upgrades versus downgrades. Since we stack upgrades and downgrades in our estimations, we multiply all control variables by a variable that equals 1 for upgrades and -1 for downgrades. 
Finally, to detect the possibility that the reaction to the recommendation surprise depends on the sign of the surprise (Hayn, 1995), we define one last variable ASYM, a dummy that equals one for upgrades and zero otherwise. Then, we interact $A S Y M$ with $S U R P$ to control for any asymmetric price reaction to recommendation upgrades versus downgrades. ${ }^{13}$

\section{DESCRIPTIVE STATISTICS AND BASIC RESULTS}

\subsection{Descriptive Statistics}

Table 1 reports key sample statistics. The first column refers to the whole sample. The second and third columns refer to country and sector specialists respectively. This allows us to compare the main characteristics of the portfolios of these two types of analysts. As a first insight, this table shows that the average number of firms followed by each type of analysts is very similar across specializations. On average, both country and sector specialists follow approximately eight firms. To the same extent, the average number of yearly recommendations is equivalent for both types of analysts. Country and sector specialists issue an average of 17.1 and 18.2 recommendations per year respectively. However, the focus seems to be different across specializations. Sector specialists focus on more actively followed firms. The average number of analysts following firms analyzed by sector specialists is 27.2 , which is well above the average of 16 for country specialists.

The third row of the table indicates that country specialists follow on average 1.04 countries. In fact, a country specialist may follow up to four countries. This gives support to our definition of specialization. That is, the use of Herfindahl indices allows us to consider as country specialists analysts who spend most of their time analyzing firms headquartered in a single country, but who may also follow a small number of foreign firms. The same holds true for sector specialists who follow an average of 1.09 sectors. In fact, there are sector specialists who follow up to six industries over a given year but concentrate their efforts on firms within a single sector. The average number of sectors followed by country specialists is three, which is equivalent to the average number of countries followed by sector specialists. This is surprisingly low.

\footnotetext{
13 The literature on the accuracy of earnings forecasts documents that analysts' experience also plays an important role explaining accuracy. For this reason, in unreported results, we also examine whether experience significantly explains abnormal returns to analyst recommendations and we find that it is not the case. Due to data constrains adding experience reduces significantly our sample, but our results remain virtually unchanged.
} 
Even though sector and country specialists may follow up to 25 countries and 11 sectors respectively, these figures may indicate that brokerage houses try, in many instances, to specialize on both the country and the sector dimensions.

A noticeable difference between the portfolios of country and sector specialists is the size characteristics of the covered firms. Country specialists follow on average far smaller firms than their sector counterparts. Figure 1 provides additional evidence on the size distribution of firms followed by each type of analyst. The distribution for sector specialists is clearly shifted to the right, which indicates that larger firms are more actively followed by this type of analyst.

Insert Table 1 About Here

Geographic location is also an important differentiator between country and sector specialists. Country specialists are on average located closer to the firms they follow. The average distance of 176 kilometers is mainly due to the fact that country specialists are mostly based within their country of expertise. Indeed, 87.8 percent of them are located in the same country as the firms they follow. Perhaps more interestingly, 41.3 percent of the recommendations issued by sector specialists relate to local firms. Although they follow more than three countries on average, sector specialists seem to tilt their activities towards domestically headquartered firms.

The type of brokerage house country and sector specialists work for also delivers interesting insights. Whereas country specialists are almost equally spread across large and small to medium brokerage houses (51.3 percent of them are working for large brokerage houses), 81.1 percent of sector specialists belong to large brokerage houses. An interesting statistic is provided by the two last rows of the table. These lines show how brokers organize research in general. It indicates that small- and medium-size brokerage houses are mainly country-focused. On average, 85.1 percent of the analysts employed by these institutions are country specialists. In large brokerage houses, the country dimension is less pronounced, with only about half of the analysts being country specialists. 
Table 2, panel A presents the main statistics of interest on a country-by-country basis. Panel B presents the same statistics by sectors. Surprisingly, panel A shows that the relative percentages of recommendations issued by country and sector specialists are similar across countries. On average, between 69.3 percent and 83.3 percent of the recommendations are issued by country specialists. The only exception is Ireland, where the total number of recommendations is spread equally between country and sector specialists. We are therefore unable to confirm the Kini et al. (2003) prediction according to which financial analysts are more likely to specialize by country in countries where national commonalities are largest. These percentages are more widely dispersed in the sector-by-sector analysis of panel B. The relative percentages of country and sector specialists range from 68.8 percent in the health care sector to 96.5 percent in the technology sector. An exception is the financial sector, which is followed mostly by sector specialists. The very high proportion of country specialists in the technology sector is surprising. A potential explanation may rely on the fact that firms in the technology sector are mainly small-capitalization stocks. As small firms tend to be more actively followed by country specialists, this may indeed explain why country specialists dominate so reliably in the technology sector.

Table 2 also gives strong support to the firm-size characteristics already reported at the global level. Indeed, the small-firm bias of country in relation to sector specialists is not peculiar to a specific country or sector. Country specialists follow smaller firms than sector specialists in every country and sector. On average, firms followed by country specialists are a third the size of those followed by sector specialists.

\section{Insert Figure 1 About Here}

The country-by-country average distance for sector specialists ranges from 334 to a high of 1,349 kilometers. The average distance between sector specialists and the firms they follow is greatest for Austria, Finland, and Portugal. Also, the percentage of local sector specialists is relatively low in these countries, below 3.1 percent. To the contrary, the average distance for sector specialists in large markets such as France, Germany, and the UK is 385, 668, and 353 kilometers respectively. The percentage of local sector specialists is also far more important than in small markets. Altogether, this may show that large brokerage houses are reluctant to put business branches in small markets. 
In table 3, we report the distribution of recommendations. We first note that the conclusions are not much different from those reported in studies on the U.S. market. In European countries, as in the U.S. market, analysts are reluctant to issue strong sell recommendations, but this type of recommendation occurs slightly more often in Europe than in the U.S., representing 6.3 percent of the total recommendations issued over the sample period. Our aim in constructing this table was to check whether there were significant differences in the behavior of both country and sector specialists. It could be that potential conflicts of interest affect country and sector specialists differently, or that one group is more optimistic than the other. If country analysts have better access to private information, they may be tempted to issue positively biased forecasts in order to preserve their privileged relationships with firms' management. On the other hand, sector specialists could be those who are the most affected by conflicts of interest, as this type of analyst generally works for larger banks and brokerage houses, which are more likely to be active in the investment banking industry.

\section{Insert Table 3 About Here}

Table 3 indicates that there does not seem to be a difference in the behavior of the two groups of analysts. In fact, country specialists tend to issue more extreme recommendations than sector specialists. They issue on average a higher percentage of strong buy, as well as a higher percentage of strong sell recommendations. As is shown by the F-statistics for the difference in means, both differences are statistically significant, even though they do not appear to be economically large. Sector specialists, on the other hand, seem to rely more heavily on hold recommendations than their country specialist peers. 


\subsection{Does the Information Content of Recommendations Depend on Specialization?}

Before investigating whether the information content of recommendations depends on whether analysts are country or sector specialists, it is crucial to confirm that stock recommendations on European firms do contain valuable information. This has been shown to be the case within the US market, but we have limited knowledge about the value of stock recommendations in Europe. To this end, we first estimate model (1). ${ }^{14}$

Results are presented in Table 4. As reported in the context of the US market, column (1) shows that the initial stock price reaction is positively related to recommendation changes. Columns (2) and (3) further show that there is also a drift that appears to last at least up to 60 days following the recommendation release. All of the coefficients on SURP are statistically significant at high confidence levels. In columns (4) to (6) we add various control variables. The initial stock price reaction related to broker size is strongly significant and similar to what is reported by Stickel (1995) in the context of the US market. In addition to a contemporaneous relationship, the price drift continues to be related to brokerage size, which emphasizes the need to control for broker size in subsequent tests.

Then we observe that the number of analysts covering the firm is also a significant determinant of the amount of information contained in stock recommendations. This supports the notion that the firms' information environment may play a role in the strength of market participants' reaction to newly issued recommendations. Precisely, we find that the market tends to react contemporaneously more to stock recommendations issued on firms with extensive analyst coverage. This finding contrasts with our prediction outlined in section 4 that the relation between NUMANA and the price reaction to recommendations releases was expected to be negative. It also evidences that the relation between the information environment and the price reaction to analyst recommendations is complex. In fact, there are some studies such as Bailey, Karolyi and Salva (2006) among others, that document a positive association.

\footnotetext{
${ }^{14}$ Even though it has been shown that the recommendation changes are more relevant that the recommendation levels, in alternative tests we also control for the level of stock recommendations. We follow two alternative approaches. First we define a variable that we call SURP Level and it is constructed as follows: it is the SURP variable multiplied by 2 if the newly issued recommendation is a strong buy or strong sell, multiplied by 1 if it is a buy or a sell and by 0 if it is a hold. Then we replace SURP by SURP.Level in the regressions. A second approach to control for the level of the recommendation together with the magnitude consists on adding a dummy variable to the basic regressions that takes value 1 if the recommendation is a strong buy or a strong sell. Given that controlling for the level of the recommendation in any of the two described approaches does not alter our inferences we do not report the results here, but they are available upon request from the authors.
} 
Then when we look at column (5) and (6), the the association between NUMANA and price reaction reverses and becomes negative. Overall, we find that NUMANA is negatively related to the cumulative price reaction over the period $[-1,+60]$. [Write this up in section 4.]

Among the variables aimed at capturing differences due to contemporaneous earnings announcements, $C A G E$ appears to be the most significant. Indeed, recommendations issued on the same day as earnings announcements look as if they convey significantly more information than recommendations issued at other times. Probably, this result reinforces the idea that one has to control for contemporaneous earnings announcements to avoid the confounding effects of these two simultaneous pieces of information brought to the market. TIMELINESS is negative and significant across specifications indicating that recommendations following other recommendations issued on the same firm are less informative than fresh and newly issued recommendations. In column (4), ASYM is not statistically significant which suggests that there is no asymmetry in the initial stock price reaction to upgrades and downgrades. This result contrasts to what is observed for US recommendations: a stronger price reaction for downgrades than for upgrades. Surprisingly, in column (5) and (6) the price drift following the recommendation release is stronger for upgrades than downgrades while for US recommendations we tend to observe the reverse. However, we note that this is consistent with the results reported in Jegadeesh and Kim (2006) who find no asymmetric price response to upgrades and downgrades or even a stronger price reaction to upgrades in several of the G7 countries (i.e. Canada, UK, Italy).

Insert Table 4 About Here

Overall, Table 4 confirms that recommendations on European firms do convey valuable information as in the U.S. market. Also, most of the characteristics considered, which have been shown to affect the information content of recommendations within the US market significantly, turn out to be significant in the context of Europe as well. Therefore, in all the regression models we estimate in the rest of the paper, we include all of these variables as controls. 
We previously discussed that analysts' portfolios were shaped by the information environment and the existence of common forces driving firm's earnings. We also argued that other forces also affect how analysts define their portfolios. If this is true, the composition of analysts' portfolios and particularly analysts' specialization may be important in determining the relative level of information contained in stock recommendations. We expect that recommendations issued by analysts whose portfolios benefit most from commonalities across firms are more informative of the true value of the firm. Having shown that European stock recommendations affect prices significantly, we now turn to the analysis of whether recommendations issued by country and sector specialists provide investors with differing levels of information.

To test for the relative information content of recommendations from country and sector specialists, we estimate model (2). Table 5 presents the results. Column (1) shows no significant difference between the price reaction to recommendations issued by country and sector specialists. However, column (4) shows a different picture when we control for the various dimensions that can also influence the price reaction. We observe that at the time of the recommendation release, the stock price reaction is economically stronger when the recommendation is issued by a country specialist. An F-test with a p-value of 0.08 reported in the last row of column (4) confirms that this difference is statistically significant. Thus, the market seems to react differently to recommendations issued by country and sector specialists at the time of the recommendation release. Furthermore, we also observe that the price continues to drift over the window $[+2,+20]$ only for recommendations issued by country specialists though the statistical significance is only marginal. We argue that country specialists bring additional information that is not incorporated into prices at the time of the recommendation release. In contrast, the coefficients on recommendation changes issued by sector specialists are statistically insignificant; indicating that this type of analysts does not bring any new information to the market beyond what it is captured by control variables. The p-values for the tests of the difference between the coefficients on country and sector specialists support this insight.

Insert Table 5 About Here 
Country specialists seem to bring additional information that is not incorporated into prices at the time the recommendation is released, although statistical significant is only marginal. We interpret this finding as evidence that the price drift is related to the information advantage of country specialists. That is, recommendations issued by country specialists contain more information that is slowly incorporated into prices over the window $[+2,+20]$. This delayed price response could be a result of traders failing to assimilate the information provided by country specialists. It could also be explained by the existence of transaction costs that exceed the potential gains from exploiting the information. It is not possible for us to distinguish between these two possible explanations and doing so is beyond the scope of the paper. What we rule out is the possibility that the price drift is due to a change in the underlying risk, since the delayed price reaction is related to the type of analyst and not to the type of firm. Indeed, results remain similar when the sample is restricted to the subset of firms that are followed by both country and sector specialists.

\section{EXPLAINING THE DIFFERENTIAL INFORMATION CONTENT}

In the previous section, we documented that country specialists issue more valuable recommendations than sector specialists. This result could be attributed to the existence of commonalities across firms that are followed by country analysts. It could also be due to economies of scale that they realize when evaluating country factors. In particular, country factors may stem from particularities in institutional, accounting, fiscal, legal, or cultural aspects that make countries differ. Advantages linked to geographic location could also provide country specialists with the opportunity to produce higher quality recommendations. In what follows, we explore these possibilities. 
To do so, we expand our initial model in the following way:

$$
\begin{aligned}
\text { CABNRET }_{\left[t_{0} ; t_{1}\right]}=\alpha & +\beta_{c, 1} \cdot \text { SURP } \cdot \text { COUNTRYSP } \cdot \text { FACTOR } \\
& +\beta_{c, 2} \cdot \text { SURP } \cdot \text { COUNTRYSP } \cdot(1-\text { FACTOR }) \\
& +\beta_{s} \cdot \text { SURP } \cdot \text { SECTORSP }+\gamma \cdot \text { Controls }+\varepsilon
\end{aligned}
$$

where FACTOR relates to the different variables that we describe is subsequent sections and consider as potential explanatory factors of the information advantage of country specialists. This approach allows us to test whether the comparative advantage of country specialists is most apparent in certain institutional settings, or relates to specific analyst characteristics. As we argue below, we hypothesize that country specialists may draw this advantage from recommendations on firms located in countries with weaker institutions, because they benefit from a physical location advantage, or because they focus on firms headquartered in countries with strong national-specific forces. Our test of interest is therefore stated as $H_{0}: \beta_{c, 1}=\beta_{c, 2}$.

\subsection{Institutional Factors}

High-quality institutional structures (i.e., high-quality disclosure and legal system, good governance) have a positive impact on the information environment and may require less country-specific knowledge. ${ }^{15}$ A system with high-quality institutions is consistent with improved corporate governance and greater disclosure and transparency. It could be that high-

quality institutions (quality disclosure and corporate governance) affect the economies of scale that can be realized with specialization and a good understanding of country institutions. Another possibility is that better disclosure and governance imply a lower correlation of firm future earnings with the potential information and agency costs that arise with poor-quality institutions. In poor governance settings, firm value may be affected to a larger extent by agency problems that are common to all firms subject to the same legal rules. In this setting, country specialists may be at an advantage in understanding the extent to which agency problems affect value for this group of firms. This advantage disappears as agency costs are reduced through improved governance. 
Therefore better disclosure and governance may lead to lower commonalities across firms' future earnings. There is still another possibility to explain why high-quality institutions may lower the benefits from specialization. An enhanced information environment makes it less costly to acquire and process information not only for analysts but for investors in general. Potential economies of scale being less relevant, it could be that analysts' information advantage over the market diminishes. If these institutional particularities play a role in the way analysts can process information and benefit from economies of scale, then we expect to find that the information advantage of country over sector specialists occurs only for firms located in countries with poorer disclosure standards and corporate governance.

In our analysis, we include country-level variables that allow us to explore whether corporate governance and the quality of disclosure play a role in the results we document. Following the corporate governance literature, we define the variable PROT as a measure for the quality of legal protection offered to minority investors in a given country. PROT is the anti-director rights index as presented in La Porta et al. (1998). The index ranges from 0 to 5 , and it measures the strength of laws and regulations in each country that aim to protect minority shareholders. Following the disclosure literature, we also consider the ACTG index produced by the Center for International Financial Analysis and Research and used by La Porta et al. (1998). It is a measure of the quality of accounting standards in the country where firms are incorporated. ${ }^{16}$ Specifically, we define a high protection (HPROT) dummy variable that equals 1 if the anti-director rights index is above the sample median value and 0 otherwise. We also define a dummy variable for high disclosure, HACTG, which equals 1 if the $A C T G$ index is above the sample median and 0 otherwise. Also, we consider total market capitalization as a proxy for the extent to which each country's financial market is developed. This variable has been widely used as a proxy for the quality of the information environment. We divide our sample into high and low national market capitalization, and set the dummy variable HMKTSIZE equal to 1 if market capitalization is above the median and 0 otherwise. Therefore, we successively set FACTOR = HACTG, HPROT, and HMKTSIZE.

\footnotetext{
${ }^{15}$ Ball et al. (2000), Morck et al. (2000), Rajan and Zingales (2003) and Chang et al. (2001) show how institutions impact the information environment.

${ }^{16}$ International Accounting and Auditing Trends ( $4^{\text {th }}$ edition, 1997), Center for International Financial Analysis and Research, Princeton, New Jersey.
} 
Results are presented in Table 6, panel B. In what follows, for comparison purposes we report in Table 6, panel A the main results from Table 5. Also, we do not report the coefficients on control variables, so as to avoid presenting extensive tables. ${ }^{17}$ With regards to estimations for both accounting index and anti-director rights, we first remark that the initial stock-price reaction does not depend on whether recommendations are issued in high or low accounting index or anti-director rights countries. In fact, the overall information content of stock recommendations issued by country specialists is similar in countries with high- and low -quality institutions. However, the post recommendation price reaction is stronger for those recommendations issued by country specialists that refer to firms located in countries with lower quality institutions. The coefficients on country specialists after the initial stock price reaction are all positively and significantly related to cumulative abnormal returns only in low accounting index and anti-director right countries. Coefficients on sector specialists do not show any statistical significance in any case. Second, the additional information brought to the market by country specialists is more pronounced in low ACTG and PROT countries. Coefficients on country specialists in countries with low institutional variables are always larger than those in countries with high institutional variables and the difference between coefficients is statistically significant.

In table 6 , the last section of panel $\mathrm{B}$ focuses on the breakdown by stock market capitalization of the country in which the firm is located. This is an ad hoc check of whether the relative advantage of country specialists is concentrated in firms for which the information environment is poorer. In such markets, country-specialized analysts may obtain benefits from commonalities that are supposedly large. Indeed, the comparison of the coefficients on recommendations issued by country specialists in small and large markets reveals that the information content of recommendations is more pronounced in the former. Here, this differential informativeness is partly acknowledged by investors, as the difference is statistically significant at the time of the recommendation release (p-value: 0.048).

Insert Table 6, panel A and B

\footnotetext{
${ }^{17}$ Complete tables with coefficients on control variables are available from the authors upon request.
} 
Overall, these results suggest that institutional factors may explain part, but not all, of the informational advantage of country specialists over sector specialists. On average, country specialists issue more informative recommendations in small countries and countries with low accounting standards and low minority shareholder protections. Moreover, the information content of stock recommendations issued by country specialists remains higher than for sector specialists even in large markets and when accounting standards and shareholder protection are high. We acknowledge that the information advantage is only gradually incorporated into stock prices especially in countries with poorer quality institutions.

\subsection{Proximity Factors}

A few papers study information asymmetries due to proximity in the context of financial analysis. Bae et al. (2005) report accuracy differences depending on whether analysts are based within the same country as the firms they evaluate. Relying on a sample of 32 countries, their results show that local analysts issue on average far more accurate earnings forecasts than their foreign peers. In the context of European markets, Orpurt (2004) reports a similar result. Malloy (2005) studies the difference in accuracy between analysts located close to the firms they follow and those farther away. He concludes that, within the US, geographically proximate analysts issue on average more accurate earnings forecasts. Whereas Malloy focuses on physical proximity and uses measures that capture distance between analysts and firms, Bae et al. (2005) and Orpurt (2004) focus on different measures of proximity; that is, local versus foreign analysts. Being local reflects not only physical proximity but also other dimensions of proximity such as cultural, economic or institutional. These papers do not try to evaluate which dimension of proximity is relevant, probably because data on physical distance is hard and tedious to get.

In this paper, we capture these two dimensions of proximity. First, we compute the distance between analysts and the firms they follow. Second, we classify analysts as local or foreign, depending on whether they are located in the same country as the firms they follow or abroad. These two geographic dimensions do not have the same implications for sources of information advantage. In the first case, analysts may have better access to private information, as they are located close to the firms' headquarters. They can visit the firm on a regular basis and build solid relationships with management. In the second case, the advantage that local analysts may have is more likely related to better knowledge of country characteristics. One may think of language, fiscal policies, regulations and cultural and institutional dimensions. [ add sonney 2007) 
Therefore, we make a clear distinction between the advantage due to being local, as opposed to foreign, and the physical proximity advantage, as opposed to being located geographically far away from firms' headquarters. To compute the variables that relate to these two dimensions, we proceed as follows. We first take from I/B/E/S analysts' names and the brokerage houses they work for. Then, year by year, we search in different editions of the Nelson Information's Directory and obtain the city in which each financial analyst is located. Finally, for each recommendation with available geographic information on the analyst and the firm, we compute the distance between the analyst who issued the forecast and the firm for which the forecast was issued. ${ }^{18}$ We define a dummy variable called DISTANCE that equals 1 if the analyst is located less than 100 kilometers away from the firm and 0 otherwise $^{19}$. From the same information set, we also determine whether analysts are located within the same country as the firms they follow. For each recommendation, we compute $L O C A L$, a dummy variable that equals 1 if the analyst and the firm are located in the same country and 0 otherwise.

The results are reported in Table 6, Panel C. Surprisingly, within-country location does not appear as a potential explanation for the better performance of country specialists. In fact, the coefficients are larger for local than for foreign country specialists and sector specialists but they are not statistically significant. We note that the lack of statistical significance of these results may come from a sharp reduction in the size of the sample, coupled with the fact that only a small portion of country specialists are located abroad.

Results for proximity as defined by analysts being located geographically close to the firms, also lack statistical significance. Both proximate and more distant country specialists outperform sector specialists, and the coefficients on these two types of country specialists are close to each other in the first two periods. However, the coefficients are not statistically significant. As such, it seems that proximity is not a source of advantage. But we remain careful in our interpretation as these tests certainly suffer from the same data availability problem as before.

\footnotetext{
${ }^{18}$ The formula used to compute the distance (Dist) between to cities $A$ and $B$ is given by Dist $=R \arccos \left[\sin \left(\right.\right.$ latitude $\left._{A}\right) \sin \left(\right.$ latitude $\left._{B}\right)+\cos \left(\right.$ latitude $\left._{A}\right) \cos \left(\right.$ longitude $_{B}-$ longitude $\left.\left._{A}\right)\right]$, where $R=6378 \mathrm{~km}$ is the earth's radius.

${ }^{19}$ Results are unchanged with thresholds of either 50 or 200 kilometers.
} 
Insert Table 6, panel C

\subsection{Country Factors}

Country factors represent common economic forces driving firms' future earnings beyond those related only to institutional factors. In this section, we test whether country factors explain the advantage of country over sector specialists. For that purpose, we follow Heston and Rouwenhorst (1994) and estimate from stock index returns the "pure" country factors. This method returns, for each country in the sample, a time series of country factors. We then compute, on an annual basis, the variance of each country factor. It serves as a proxy for the strength of national influences in the country. Countries with important national specificities have a high country-factor variance. We then rank countries on the basis of their country factor variance. Recommendations issued on firms in countries with a country factor above the median country factor are classified as high country-factor recommendations. The dummy variable HFACTOR takes the value 1 for recommendations issued in these countries and 0 otherwise.

We hypothesized that country specialists may draw their relative advantage from countries in which commonalities among firms are large. If so, recommendations issued by country specialists on firms in countries with high country factors should convey more information than recommendations in countries with low country factors. Results are reported in table 6, panel $\mathrm{D}$ and they marginally confirm our hypothesis. The initial stock price reaction is identical for recommendations issued by country specialists in low and high country-specific factor markets. These coefficients are 0.08 and 0.07 percent respectively, and the test for their statistical difference reports a p-value of 0.779 . However, the coefficient on country specialists in countries with high commonalities is much larger than the coefficient on country specialists in low commonalities countries in the $[+21 ;+60]$ period and the difference is significant at the $10 \%$ level.

Insert Table 6, panel D 
As an alternative measure for country factors we also consider the raw country standard deviation of stock returns. HSTDEV takes the value 1 for recommendations issued in countries where return variance is above the median value and 0 otherwise. Results are also reported in table 6, panel D. We observe that the contemporaneous and subsequent stock price reaction is larger for recommendations issued by country specialists in countries with high country-specific variance. The difference is statistically significant for the periods $[-1,+1]$ and $[+21,+60]$ with p-values of 0,053 and 0,008 respectively. Overall our results suggest that country factors could also explain part of our findings as the coefficients are significantly larger when country factors are high (especially for $H S T D E V$ ) showing that in that case country specialists add more value.

\section{CONCLUSION}

Brokerage houses usually organize their European research departments along either country or sector lines. Their research activities aim to provide valuable information and advice to investors. Our goal is to evaluate which form of organization provides most value to investors. In this paper, we document that the value contained in analysts' stock recommendations is related to how analysts structure their portfolios and research activities. We compare the information content of stock recommendations issued by country specialists and sector specialists. We show that the former outperform sector specialists, in the sense that their recommendations convey more information to the market.

We investigate potential sources of the information advantage country specialists enjoy. Results show that the information content of their recommendations is higher in countries with low accounting standards and weak shareholder protection. It is also higher for firms located in countries with low market capitalization. Our results, however, indicate that geographical and cultural proximity provides a weak explanation for the superior performance of country specialists. Thus, location and proximity does not seem to be a source of comparative advantage, contrary to what some studies document for earnings forecast accuracy. Last, we observe that the relatively better performance of country specialists is highest in countries with relatively strong country-specific factors. 
The information advantage of country specialists is not short-lived. There is an incomplete price reaction at the time the recommendation is released that continues to drift for up to 60 days. This delayed price response could be the result of traders failing to assimilate the information provided by country specialists. It could also be explained by the existence of transaction costs that exceed the potential gains from exploiting the information. It is not possible for us to distinguish between these two possible explanations, and doing so is beyond the scope of the paper. What we rule out is the possibility that the price drift is due to a change in the underlying risk, since the delayed price reaction is related to the type of analyst and not to the type of firm. 


\section{REFERENCES}

Adjaouté, K., and J.-P. Danthine. (2003). "European Financial Integration and Equity Returns: A Theory Based Assessment.” In V. Gaspar, P. Hartmann, and O. Sleijpen (Eds.), The Transformation of the European Financial System, Chapter 5, pp. 185-245.

Asquith, P., M. B. Mikhail, and A. S. Au. (2005). "Information Content of Equity Analyst Report.” Journal of Financial Economics 75, 245-282.

Baca, S. P., B. L. Garbe, and R. A. Weiss. (2000). "The Rise of Sector Effects in Major Equity Markets." Financial Analysts Journal 56, 34-40.

Bae, K.-H., R. M. Stulz, and H. Tan. (2005). "Do Local Analysts Know More? A CrossCountry Study of the Performance of Local Analysts and Foreign Analysts." Journal of Financial Economics, forthcoming.

Ball, R., S. Kothari, and A. Robin. (2000). "The Effect of International Institutional Factors on Properties of Accounting Earnings." Journal of Accounting and Economics 29, 1-51.

Barber, B., R. Lehavy, M. McNichols, and B. Trueman. (2001). "Can Investors Profit from the Prophets? Security Analyst Recommendations and Stock Returns." Journal of Finance 56, 531-563.

Beckers, S., G. Connor, and R. Curds. (1996). "National versus Global Influences on Equity Returns.” Financial Analysts Journal 52, 31-39.

Berger, A. N., N. H. Miller, M. A. Petersen, R. J. Rajan, J. C. Stein. (2005). "Does Function Follow Organizational Form? Evidence from the Lending Practices of Large and Small Firms.” Journal of Financial Economics 76, 237-269.

Boni, L., and K. L. Womack. (2004). “Analysts, Industries, and Price Momentum.” Tuck School of Business at Darmouth, Working paper No. 2004-12.

Bradshaw, M. T. (2004). "How Do Analysts Use Their Earnings Forecasts in Generating Stock Recommendations." The Accounting Review 79, 25-50. 
Brown, S., and J. Warner. (1985). "Using Daily Stock Returns: The Case of Event Studies." Journal of Financial Economics 14, 3-31.

Cavaglia, S., C. Brightman, and M. Aked. (2000). "The Increasing Importance of Industry Factors." Financial Analysts Journal 56, 41-54.

Chang, J.J., T. Khanna, and K. Palepu. (2000). “Analyst Activity round the World.” Havard Business School Working Paperx.

Clement, M. B. (1999). “Analyst Forecast Accuracy: Do Ability, Resources, and Portfolio Complexity Matter?" Journal of Accounting and Economics 27, 285-303.

Clement, M. B., L. Rees, and E. P. Swanson. (2003). “The Influence of Culture and Corporate Governance on the Characteristics That Distinguish Superior Analysts." Journal of Accounting, Auditing and Finance 18, 593-618.

Coval, J., and T. Moskowitz. (2001). "The Geography of Investment: Informed Trading and Asset Prices.” Journal of Political Economy 109, 811-841.

Demirakos, E. G., N. Strong, and M. Walker. (2005). "What Valuation Models do Analysts Use?" Accounting Horizons, forthcoming.

Duru, A., and D. M. Reeb. (2002). "International Diversification and Analysts' Forecast Accuracy and Bias." The Accounting Review 77, 415-433.

Francis, J., and L. Soffer. (1997). "The Relative Informativeness of Analysts' Stock Recommendations and Earnings Forecast Revisions." Journal of Accounting Research 35, 193-211.

Galati, G., and K. Tsatsaronis. (2001). "The Impact of the Euro on Europe's Financial Markets.” BIS Working Paper No. 100.

Available at http://www.bis.org/publ/work100.pdf

Griffin, J. M., and A. G. Karolyi. (1998). "Another Look at the Role of the Industrial Structure of Markets for International Diversification Strategies." Journal of Financial Economics 50, 351-373. 
Haw, I., K. Jung, and W. Ruland. (1994). “The Accuracy of Financial Analysts Forecasts after Mergers." Journal of Accounting, Auditing and Finance 9, 465-483.

Heston, S. L., and G. K. Rouwenhorst. (1994). "Does Industrial Structure Explain the Benefits of International Diversification?” Journal of Financial Economics 36, 3-27.

Heston, S. L., and G. K. Rouwenhorst. (1995). "Industry and Country Effects in International Stock Returns.” Journal of Portfolio Management 21, 53-58.

Ivkovic, Z., and N. Jegadeesh. (2004). "The Timing and Value of Forecast and Recommendation Revisions.” Journal of Financial Economics 73, 433-463.

Jegadeesh, N., and W. Kim. (2006) "Value of Analyst Recommendations: International Evidence.” Journal of Financial Markets 9, 274-309.

Jegadeesh, N., J. Kim, S. D. Krische, and C. M. C. Lee. (2004). “Analyzing the Analysts: When Do Recommendations Add Value?” Journal of Finance 59, 1083-1124.

Kini, O., S. Mian, M. Rebello, and A. Venkateswaran. (2003). "On the Determinants of International Analyst Research Coverage." SSRN Working Paper. Available at http://papers.ssrn.com/sol3/papers.cfm?abstract_id=424042

La Porta, R., F. Lopez-de-Silanes, A. Shleifer, and R. Vishny. (1998). "Law and Finance". Journal of Political Economy 106, 1113-1155.

Lang, M., and R. Lundholm. (1996). "Corporate Disclosure Policy and Analyst Behaviour." The Accounting Review 71, 467-492.

Lo, R., and G. M. Mian. (2005). "Do Accurate Earnings Forecasts Facilitate Superior Investment Recommendations?" Journal of Financial Economics, forthcoming.

Malloy, C. J. (2005). “The Geography of Equity Analysis.” Journal of Finance 60, 719-755.

Maynes, E. M., and J. Rumsey. (1993). "Conducting Event Studies with Thinly Traded Stocks.” Journal of Banking and Finance 17, 145-157. 
Morck, R., B. Yeung, and W. Yu. (2000). “The Information Content of Stock Markets: Why do Emerging Markets Have Synchronous Stock Price Movements?" Journal of Financial Economics 59, 215-238.

Orpurt, S. F. (2003). "Local Asymmetric Information Advantages: International Evidence from Analysts' European Firm Earnings Forecasts." School of Accountancy, Singapore Management University, Working Paper \#2003/04-01. Available at http://www.accountancy.smu.edu.sg/Research/seminar/pdf/Orpurt.pdf

Petersen, M.A., and R.G. Rajan. (2002). "Does Distance Still Matter? The Information Revolution in Small Business Lending.” Journal of Finance 57, 2533-2570.

Plumlee, M. (2003). "The Effect of Information Complexity on Analysts use of that Information." The Accounting Review 78, 275-296.

Rajan, R.G., and L. Zingales. (2003). "Banks and Markets: The Changing Character of European Finance.” NBER working paper.

Rubino, J. (2003). “The New Global Industry Analysis.” The CFA Magazine, July-August, 46-47.

Schipper, K. (1991). “Analysts’ Forecasts.” Accounting Horizons 5, 105-131.

Sonney, Frédéric, (2005). "Sector versus Country Specialization and Financial Analysts' Performance", Review of Financial Studies, forthcoming.

Stein, J. (2002). "Information Production and Capital Allocation: Decentralized versus Hierarchical Firms.” Journal of Finance 57, 1891-1921.

Stickel, S. E. (1995). "The Anatomy of the Performance of Buy and Sell Recommendations." Financial Analysts Journal 51, 25-39.

Womack, K. L. (1996). "Do Brokerage Analysts' Recommendations Have Investment Value?" Journal of Finance 51, 137-167. 


\section{FIGURE 1}

Size distribution of firms followed by country and sector specialists

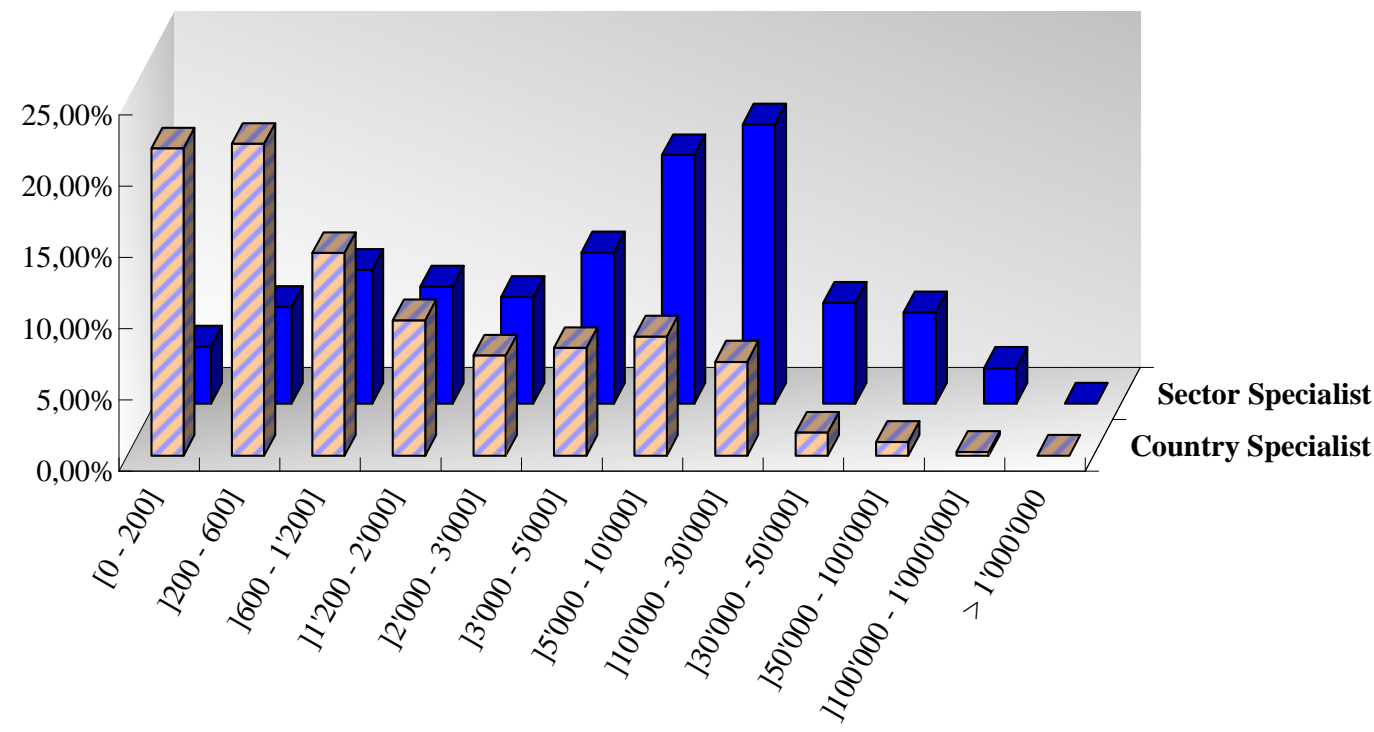

\begin{tabular}{|c|c|c|}
\hline $\begin{array}{l}\text { Firm size } \\
\text { (mio. EUR) }\end{array}$ & $\begin{array}{l}\text { Country } \\
\text { Specialist }\end{array}$ & $\begin{array}{c}\text { Sector } \\
\text { Specialist }\end{array}$ \\
\hline [0 - 200] & $21,55 \%$ & $4,02 \%$ \\
\hline ]200 - 600] & $21,88 \%$ & $6,79 \%$ \\
\hline ]600 - 1'200] & $14,22 \%$ & $9,39 \%$ \\
\hline ]1'200 - 2'000] & $9,50 \%$ & $8,22 \%$ \\
\hline ]2'000 - 3'000] & $7,02 \%$ & $7,50 \%$ \\
\hline ]3'000 - 5'000] & $7,55 \%$ & $10,60 \%$ \\
\hline$\left.]^{\prime} 000-10^{\prime} 000\right]$ & $8,34 \%$ & $17,45 \%$ \\
\hline ]10'000 - 30'000] & $6,59 \%$ & $19,59 \%$ \\
\hline ]30'000 - 50'000] & $1,63 \%$ & $7,09 \%$ \\
\hline ]50'000 - 100'000] & $0,96 \%$ & $6,40 \%$ \\
\hline ]100'000 - 1'000'000] & $0,26 \%$ & $2,51 \%$ \\
\hline$>1^{\prime} 000^{\prime} 000$ & $0,00 \%$ & $0,00 \%$ \\
\hline
\end{tabular}




\section{Table 1. Descriptive Statistics}

This table presents average values of various characteristics of analysts' portfolios and research activities, depending on specialization. We include all analysts following European firms. However, to reach a clear picture of analyst portfolio characteristics, a worldwide sample of firms is considered in some instances. The reason is that sector specialists do not (always) restrict themselves to European firms and the comparison with country specialists would be worthless if one considered European firms only. "Avg. number of firms," "Avg. number of recommendations," "Avg. number of countries," and "Avg. number of sectors" indicate the average number of firms each specialization type of analysts follows, the average number of recommendations issued by analysts, and the average number of countries and sectors followed by analysts. All of these variables are computed on a yearly basis from a worldwide sample of firms. The rest of the table refers to a sample restricted to European firms. "Avg. number of analysts per firm" is an indication of the average number of analysts who follow a given firm on a yearly basis. "Avg. firm size" is the average market capitalization of firms in analysts' portfolios. "Avg. market size" is the average size of the national markets followed by analysts. "Avg. distance" is the average number of kilometers between analysts and the firms they follow. "Local" stands for analysts located in the same country as the firms they follow. By contrast, "foreign" analysts are based abroad. "Large brokers" are those in the top broker size-decile. "Small and medium brokers" constitute the remainder. The percentage of analysts in large and small/medium brokerage houses indicates for which type of brokers financial analysts work. "Brokerage structure", which is reported in the last two rows of the table, indicates which type of analysts large and small/medium brokerage houses tend to employ.

\begin{tabular}{lrrr}
\hline Variable & All Analysts & $\begin{array}{c}\text { Country } \\
\text { Specialists }\end{array}$ & $\begin{array}{c}\text { Sector } \\
\text { Specialists }\end{array}$ \\
\hline Avg. number of firms & 8,1 & 8,4 & 7,9 \\
Avg. number of recommendations & 17,0 & 17,1 & 18,2 \\
Avg. number of countries & 1,60 & 1,04 & 3,33 \\
Avg. number of sectors & 2,69 & 3,22 & 1,09 \\
Avg. number of analysts per firm & 18,7 & 16,0 & 27,2 \\
Avg. firm size (mio. EUR) & $7.818,9$ & $4.911,0$ & $17.152,0$ \\
Avg. market size (bio. EUR) & 867 & 869 & 864 \\
Avg. distance (km) & 307 & 176 & 595 \\
$\%$ of local analysts & $65,4 \%$ & $87,8 \%$ & $41,3 \%$ \\
$\%$ of foreign analysts & $34,6 \%$ & $12,2 \%$ & $58,7 \%$ \\
$\%$ of analysts in large brokerage & $60,0 \%$ & $51,3 \%$ & $81,1 \%$ \\
$\%$ of analysts in small/medium brokerage & $40,0 \%$ & $48,7 \%$ & $18,9 \%$ \\
Large brokers' structure & $100,0 \%$ & $58,4 \%$ & $41,6 \%$ \\
Small/medium brokers' structure & $100,0 \%$ & $85,1 \%$ & $14,9 \%$ \\
\hline
\end{tabular}




\section{Table 2. Descriptive Statistics: Country-by-Country and Sector-by-Sector}

This table reports statistics of interest on a country-by-country (panel A) and a sector-by-sector (panel B) basis. In both panels, column 2 reports the total number of analysts having issued recommendations on firms headquartered in the corresponding country (panel A) or sector (panel B) over the period 1994 - 2003 . Columns 3 to 6 give the total number and percentage of recommendations issued by country and sector specialists over the whole sample period in the corresponding country or sector. Columns 7 and 8 report the average size of firms in respectively country and sector specialists' portfolios. Columns 9 and 10 indicate the average distance (in kilometers) that separates country and sector specialists and the firms they follow. The last two columns report the percentage of local analysts (i.e., based within the same country as firms) having issued recommendations on firms in the corresponding country (panel A) or sector (panel B).

Panel A

\begin{tabular}{|c|c|c|c|c|c|c|c|c|c|c|c|}
\hline \multirow{2}{*}{ Country } & \multirow{2}{*}{$\begin{array}{l}\text { Total } \\
\text { number } \\
\text { of } \\
\text { analysts }\end{array}$} & \multicolumn{4}{|c|}{ Total number of recommendations } & \multicolumn{2}{|c|}{$\begin{array}{l}\text { Avg. firm size } \\
\text { (mio EUR) }\end{array}$} & \multicolumn{2}{|c|}{$\begin{array}{l}\text { Avg. distance } \\
\text { (kilometers) }\end{array}$} & \multicolumn{2}{|c|}{$\%$ of local analysts } \\
\hline & & $\begin{array}{l}\text { Country } \\
\text { Specialist }\end{array}$ & $\%$ & $\begin{array}{c}\text { Sector } \\
\text { Specialist }\end{array}$ & $\%$ & $\begin{array}{l}\text { Country } \\
\text { Specialist }\end{array}$ & $\begin{array}{c}\text { Sector } \\
\text { Specialist }\end{array}$ & $\begin{array}{l}\text { Country } \\
\text { Specialist }\end{array}$ & $\begin{array}{c}\text { Sector } \\
\text { Specialist }\end{array}$ & $\begin{array}{c}\text { Country } \\
\text { Specialist }\end{array}$ & $\begin{array}{c}\text { Sector } \\
\text { Specialist }\end{array}$ \\
\hline Austria & 189 & 1.423 & $71,0 \%$ & 582 & $29,0 \%$ & 760 & 1.650 & 507 & 1.349 & $55,6 \%$ & $0,0 \%$ \\
\hline Belgium & 516 & 5.399 & $78,1 \%$ & 1.510 & $21,9 \%$ & 2.222 & 9.595 & 43 & 357 & $84,5 \%$ & $2,3 \%$ \\
\hline Denmark & 401 & 4.130 & $73,2 \%$ & 1.515 & $26,8 \%$ & 9.280 & 32.967 & 190 & 629 & $67,9 \%$ & $11,3 \%$ \\
\hline Finland & 413 & 6.278 & $82,4 \%$ & 1.337 & $17,6 \%$ & 2.820 & 7.501 & 138 & 1.212 & $88,8 \%$ & $1,8 \%$ \\
\hline France & 1.816 & 38.980 & $83,3 \%$ & 7.817 & $16,7 \%$ & 3.627 & 14.069 & 169 & 385 & $90,6 \%$ & $22,2 \%$ \\
\hline Germany & 1.510 & 21.929 & $76,1 \%$ & 6.893 & $23,9 \%$ & 4.830 & 14.516 & 283 & 668 & $82,1 \%$ & $15,6 \%$ \\
\hline Ireland & 205 & 598 & $48,7 \%$ & 629 & $51,3 \%$ & 1.791 & 6.462 & 165 & 531 & $52,2 \%$ & $4,1 \%$ \\
\hline Italy & 748 & 8.874 & $73,5 \%$ & 3.198 & $26,5 \%$ & 2.907 & 8.413 & 225 & 982 & $84,9 \%$ & $2,6 \%$ \\
\hline Netherlands & 1.097 & 18.923 & $82,2 \%$ & 4.095 & $17,8 \%$ & 5.560 & 17.168 & 98 & 334 & $81,1 \%$ & $10,6 \%$ \\
\hline Norway & 439 & 4.918 & $77,6 \%$ & 1.419 & $22,4 \%$ & 10.642 & 26.369 & 182 & 895 & $91,0 \%$ & $10,1 \%$ \\
\hline Portugal & 259 & 2.690 & $75,4 \%$ & 880 & $24,6 \%$ & 1.234 & 5.265 & 1.014 & 1.338 & $72,1 \%$ & $3,1 \%$ \\
\hline Spain & 710 & 9.139 & $72,6 \%$ & 3.441 & $27,4 \%$ & 2.967 & 11.084 & 250 & 1.101 & $84,5 \%$ & $9,7 \%$ \\
\hline Sweden & 785 & 7.273 & $69,3 \%$ & 3.222 & $30,7 \%$ & 23.873 & 48.257 & 173 & 974 & $89,7 \%$ & $19,1 \%$ \\
\hline Switzerland & 804 & 8.013 & $69,7 \%$ & 3.482 & $30,3 \%$ & 10.336 & 41.192 & 154 & 760 & $88,0 \%$ & $2,9 \%$ \\
\hline UK & 2.017 & 51.390 & $79,8 \%$ & 13.046 & $20,2 \%$ & 2.426 & 11.445 & 126 & 353 & $97,8 \%$ & $82,0 \%$ \\
\hline All countries & 6.587 & 189.957 & $78,2 \%$ & 53.066 & $21,8 \%$ & 4.911 & 17.152 & 176 & 595 & $87,8 \%$ & $41,3 \%$ \\
\hline
\end{tabular}


Panel B

\begin{tabular}{|c|c|c|c|c|c|c|c|c|c|c|c|}
\hline \multirow{2}{*}{ Sector } & \multirow{2}{*}{$\begin{array}{c}\text { Total } \\
\text { number } \\
\text { of } \\
\text { analysts }\end{array}$} & \multicolumn{4}{|c|}{ Total number of recommendations } & \multicolumn{2}{|c|}{$\begin{array}{l}\text { Avg. firm size } \\
\text { (mio EUR) }\end{array}$} & \multicolumn{2}{|c|}{$\begin{array}{l}\text { Avg. distance } \\
\text { (kilometers) }\end{array}$} & \multicolumn{2}{|c|}{$\%$ of local analysts } \\
\hline & & $\begin{array}{c}\text { Country } \\
\text { Specialist }\end{array}$ & $\%$ & $\begin{array}{c}\text { Sector } \\
\text { Specialist }\end{array}$ & $\%$ & $\begin{array}{c}\text { Country } \\
\text { Specialist }\end{array}$ & $\begin{array}{c}\text { Sector } \\
\text { Specialist }\end{array}$ & $\begin{array}{c}\text { Country } \\
\text { Specialist }\end{array}$ & $\begin{array}{c}\text { Sector } \\
\text { Specialist }\end{array}$ & $\begin{array}{c}\text { Country } \\
\text { Specialist }\end{array}$ & $\begin{array}{c}\text { Sector } \\
\text { Specialist }\end{array}$ \\
\hline Finance & 1.892 & 15.987 & $41,5 \%$ & 22.540 & $58,5 \%$ & 7.565 & 18.205 & 153 & 586 & $89,0 \%$ & $41,3 \%$ \\
\hline Health Care & 1.179 & 8.239 & $68,8 \%$ & 3.732 & $31,2 \%$ & 8.412 & 28.477 & 199 & 562 & $87,0 \%$ & $40,4 \%$ \\
\hline Cons. Non-Dur. & 1.863 & 21.144 & $84,4 \%$ & 3.919 & $15,6 \%$ & 3.346 & 11.844 & 185 & 338 & $86,4 \%$ & $46,3 \%$ \\
\hline Cons. Services & 3.108 & 40.121 & $85,8 \%$ & 6.667 & $14,2 \%$ & 3.480 & 7.839 & 162 & 416 & $91,0 \%$ & $48,5 \%$ \\
\hline Cons. Durables & 1.014 & 7.078 & $94,1 \%$ & 444 & $5,9 \%$ & 10.328 & 21.251 & 232 & 874 & $88,9 \%$ & $25,9 \%$ \\
\hline Energy & 777 & 5.154 & $72,8 \%$ & 1.930 & $27,2 \%$ & 22.322 & 54.528 & 128 & 572 & $89,3 \%$ & $41,9 \%$ \\
\hline Transportation & 771 & 5.489 & $85,5 \%$ & 930 & $14,5 \%$ & 2.345 & 2.901 & 180 & 575 & $94,7 \%$ & $44,9 \%$ \\
\hline Technology & 1.539 & 15.165 & $96,5 \%$ & 544 & $3,5 \%$ & 979 & 1.118 & 170 & 917 & $91,6 \%$ & $39,0 \%$ \\
\hline Basic Industries & 2.311 & 19.013 & $75,3 \%$ & 6.247 & $24,7 \%$ & 3.280 & 7.509 & 168 & 871 & $89,4 \%$ & $39,8 \%$ \\
\hline Capital Goods & 3.032 & 44.456 & $92,9 \%$ & 3.397 & $7,1 \%$ & 3.865 & 17.581 & 178 & 597 & $89,2 \%$ & $39,6 \%$ \\
\hline Public Utilities & 1.285 & 8.111 & $74,9 \%$ & 2.716 & $25,1 \%$ & 13.847 & 33.824 & 237 & 993 & $90,0 \%$ & $26,5 \%$ \\
\hline All sectors & 6.587 & 189.957 & $78,2 \%$ & 53.066 & $21,8 \%$ & 4.911 & 17.152 & 176 & 595 & $87,8 \%$ & $41,3 \%$ \\
\hline
\end{tabular}




\section{Table 3. Distribution of Recommendations}

This table reports the distribution of stock recommendations for each type of analysts' specialization. It indicates the percentages of Strong Buy, Buy, Hold, Sell, and Strong Sell recommendations issued by all analysts (irrespective of specialization), country, and sector specialists. The last but one column reports the difference between the percentage of each recommendation type issued by country and sector specialists. The p-value for the statistical significance of this difference appears in the last column.

\begin{tabular}{crrrrr}
\hline Recommendation & $\begin{array}{c}\text { All } \\
\text { Analysts }\end{array}$ & $\begin{array}{c}\text { Country } \\
\text { Specialist } \\
\text { (a) }\end{array}$ & $\begin{array}{c}\text { Sector } \\
\text { Specialist } \\
\text { (b) }\end{array}$ & $\begin{array}{c}\text { Difference } \\
\text { (a)-(b) }\end{array}$ & $\begin{array}{r}\text { Anova } \\
\text { F-statistic }\end{array}$ \\
\hline Strong Buy & $18,9 \%$ & $20,1 \%$ & $15,1 \%$ & $5,0 \%$ & 0,000 \\
Buy & $26,4 \%$ & $25,9 \%$ & $27,9 \%$ & $-2,0 \%$ & 0,000 \\
Hold & $37,2 \%$ & $36,4 \%$ & $39,9 \%$ & $-3,5 \%$ & 0,000 \\
Sell & $11,3 \%$ & $11,1 \%$ & $11,7 \%$ & $-0,6 \%$ & 0,068 \\
Strong Sell & $6,3 \%$ & $6,5 \%$ & $5,4 \%$ & $1,1 \%$ & 0,000 \\
Total & $100,0 \%$ & $100,0 \%$ & $100,0 \%$ & $0,0 \%$ & - \\
\hline
\end{tabular}




\section{Table 4. Stock Price Reaction}

This table reports the results from the estimation of the following two models:

$$
\begin{aligned}
& \text { CABNRET } T_{\left[t_{0} ; t_{1}\right]}=\alpha+\beta \cdot S U R P+\varepsilon \\
& \text { CABNRET }_{\left[t_{0} ; t_{1}\right]}=\alpha+\beta \cdot S U R P+\gamma \cdot \text { Controls }+\varepsilon
\end{aligned}
$$

Columns (1) to (3) report results relative to the estimation of the model without control variables. The estimations reported on columns (6) to (8) are performed with the whole set of control variables. CABNRET $T_{\left[t_{0} ; t_{1}\right]}$ is the cumulative abnormal return computed over different time windows. The models are successively estimated for $C A B N R E T_{[-1 ;+1]}, C A B N R E T_{[+1 ;+20]}$, and $C A B N R E T_{[+21 ;+60]}$, where the values of $t_{0}$ and $t_{1}$ are expressed in days. SURP is the surprise, or difference, between each newly issued recommendation and the last recommendation previously released by the same analyst on the same firm. The values 1 to 5 are respectively assigned to Strong Buys, Buys, Hold, Sell, and Strong Sell recommendations. SURP therefore takes discrete values that range from -4 to +4 . The set of controls variables includes BRKSIZE (a dummy variable that takes the value 1 if the recommendation was issued by an analyst working for a large brokerage house and 0 otherwise), NUMANA (the number of analysts having issued recommendations on the firms over the last 360 days), PAGE (a dummy variable that takes the value 1 if the recommendation 'P'recedes an earnings announcement date by less than 10 days and 0 otherwise), FAGE (a dummy variable that takes the value 1 if the recommendation 'F'ollows an earnings announcement date by less than 10 days and 0 otherwise), $C A G E$ (a dummy variable that takes the value 1 if the recommendation is issued contemporaneously, i.e. on the same day, to an earnings announcement), TIMELINESS (the number or recommendations issued during the previous month on the same firm) and ASYM (a dummy that equals one for upgrades and zero otherwise interacted with the surprise). As the models we estimate include both recommendation upgrades and downgrades, all our controls are multiplied by a variable that takes the value 1 if the recommendation revision is an upgrade, -1 if it is a downgrade, and zero otherwise. We report heteroskedasticity and serial correlation robust t-statistics in parenthesis below their corresponding coefficient. ${ }^{* * *},{ }^{* *}$, and ${ }^{*}$ indicate statistical significance at the $1 \%, 5 \%$ and $10 \%$ levels, respectively. 


\begin{tabular}{|c|c|c|c|c|c|c|}
\hline Variables & $\begin{array}{c}\text { CABNRET } \\
\text { (1) }\end{array}$ & $\begin{array}{c}\text { CABNRET20 } \\
\text { (2) }\end{array}$ & $\begin{array}{c}\text { CABNRET60 } \\
\text { (3) }\end{array}$ & $\begin{array}{c}\text { CABNRET } \\
\text { (4) }\end{array}$ & $\begin{array}{c}\text { CABNRET20 } \\
\text { (5) }\end{array}$ & $\begin{array}{c}\text { CABNRET60 } \\
\text { (6) }\end{array}$ \\
\hline \multirow[t]{2}{*}{$\cong$} & 0,041 & $-0,001$ & 0,088 & 0,024 & $-0,238$ & 0,177 \\
\hline & $(1,98) * *$ & $(-1,22)$ & $(0,94)$ & $(0,66)$ & $(-2,78) * * *$ & $(1,25)$ \\
\hline \multirow[t]{2}{*}{ SURP } & 0,242 & 0,217 & 0,198 & 0,074 & 0,124 & 0,101 \\
\hline & $(16,94) * * *$ & $(6,71) * * *$ & $(3,93) * * *$ & $(2,15) * *$ & $(1,59)$ & $(0,78)$ \\
\hline \multirow[t]{2}{*}{ BRKSIZE } & & & & 0,375 & 0,425 & 0,271 \\
\hline & & & & $(8,90) * * *$ & $(4,41) * * *$ & $(1,90) *$ \\
\hline \multirow[t]{2}{*}{ NUMANA } & & & & 0,009 & $-0,016$ & $-0,024$ \\
\hline & & & & $(3,52) * * *$ & $(-2,57) * * *$ & $(-2,44) * * *$ \\
\hline \multirow[t]{2}{*}{ PAGE } & & & & $-0,015$ & 0,673 & 0,268 \\
\hline & & & & $(-0,11)$ & $(2,11) * *$ & $(0,56)$ \\
\hline \multirow[t]{2}{*}{ FAGE } & & & & 0,416 & $-0,220$ & $-0,148$ \\
\hline & & & & $(3,57) * * *$ & $(-0,91)$ & $(-0,37)$ \\
\hline \multirow[t]{2}{*}{ CAGE } & & & & 0,708 & 2,307 & 0,709 \\
\hline & & & & $(2,00) * *$ & $(3,69) * * *$ & $(0,93)$ \\
\hline \multirow[t]{2}{*}{ TIMELINESS } & & & & $-0,045$ & $-0,118$ & $-0,076$ \\
\hline & & & & $(-2,88) * * *$ & $(-2,75) * * *$ & $(-1,27)$ \\
\hline \multirow[t]{2}{*}{ ASYM } & & & & 0,014 & 0,254 & 0,428 \\
\hline & & & & $(0,28)$ & $(2,28) * *$ & $(2,35) * *$ \\
\hline Observations & 46.656 & 46.637 & 49.184 & 46.654 & 46.635 & 46.182 \\
\hline Adjusted $\mathrm{R}^{2}$ & 0,007 & 0,001 & 0,000 & 0,010 & 0,003 & 0,001 \\
\hline
\end{tabular}


Table 5. Stock Price Reaction: Country versus Sector Specialization

This table reports the results from the estimation of the following two models:

$$
\begin{aligned}
& \text { CABNRET } T_{\left[t_{0} ; t_{1}\right]}=\alpha+\beta_{c} \cdot S U R P \cdot \text { COUNTRYSP }+\beta_{s} \cdot S U R P \cdot S E C T O R S P+\varepsilon \\
& \text { CABNRET } T_{\left[t_{0} ; t_{1}\right]}=\alpha+\beta_{c} \cdot S U R P \cdot C O U N T R Y S P+\beta_{s} \cdot S U R P \cdot S E C T O R S P+\gamma \cdot \text { Controls }+\varepsilon
\end{aligned}
$$

Columns (1) to (3) report results relative to the estimation of the model without control variables. The estimations reported on columns (6) to (8) are performed with the whole set of control variables. CABNRET $T_{\left[t_{0} ; t_{1}\right]}$ is the cumulative abnormal return computed over different time windows. The models are successively estimated for $C A B N R E T_{[-1 ;+1]}, C A B N R E T_{[+1 ;+20]}$, and $C A B N R E T_{[+21 ;+60]}$, where the values of $t_{0}$ and $t_{1}$ are expressed in days. SURP is the surprise, or difference, between each newly issued recommendation and the last recommendation previously released by the same analyst on the same firm. The values 1 to 5 are respectively assigned to Strong Buys, Buys, Hold, Sell, and Strong Sell recommendations. SURP therefore takes discrete values that range from -4 to +4 . COUNTRYSP (SECTORSP) is a dummy variable that is equal to 1 if the recommendation is issued by a country specialist (sector specialist) and 0 otherwise. The set of controls variables includes BRKSIZE (a dummy variable that takes the value 1 if the recommendation was issued by an analyst working for a large brokerage house and 0 otherwise), NUMANA (the number of analysts having issued recommendations on the firms over the last 360 days), $P A G E$ (a dummy variable that takes the value 1 if the recommendation 'P'recedes an earnings announcement date by less than 10 days and 0 otherwise), FAGE (a dummy variable that takes the value 1 if the recommendation 'F'ollows an earnings announcement date by less than 10 days and 0 otherwise), $C A G E$ (a dummy variable that takes the value 1 if the recommendation is issued contemporaneously, i.e. on the same day, to an earnings announcement), TIMELINESS (the number or recommendations issued during the previous month on the same firm) and ASYM (a dummy that equals one for upgrades and zero otherwise interacted with the surprise). As the models we estimate include both recommendation upgrades and downgrades, all our controls are multiplied by a variable that takes the value 1 if the recommendation revision is an upgrade, -1 if it is a downgrade, and zero otherwise. We report heteroskedasticity and serial correlation robust t-statistics in parenthesis below their corresponding coefficient. ${ }^{* * *},{ }^{* *}$, and ${ }^{*}$ indicate statistical significance at the $1 \%, 5 \%$ and $10 \%$ levels, respectively. 


\begin{tabular}{|c|c|c|c|c|c|c|}
\hline Variables & $\begin{array}{l}\text { CABNRET } \\
\text { (1) }\end{array}$ & $\begin{array}{c}\text { CABNRET20 } \\
\text { (2) }\end{array}$ & $\begin{array}{c}\text { CABNRET60 } \\
\text { (3) }\end{array}$ & $\begin{array}{c}\text { CABNRET } \\
(4)\end{array}$ & $\begin{array}{c}\text { CABNRET20 } \\
\text { (5) }\end{array}$ & $\begin{array}{c}\text { CABNRET60 } \\
\text { (6) }\end{array}$ \\
\hline \multirow[t]{2}{*}{$\pi$} & 0,000 & $-0,065$ & 0,001 & 0,023 & $-0,239$ & $-0,179$ \\
\hline & $(1,99) * *$ & $(-1,23)$ & $(0,93)$ & $(0,65)$ & $(-2,79) * * *$ & $(1,26)$ \\
\hline \multirow[t]{2}{*}{ SURP*COUNTRYSP (b) } & 0,232 & 0,002 & 0,003 & 0,076 & 0,129 & 0,112 \\
\hline & $(14,35) * * *$ & $(6,79) * * *$ & $(4,66) * * *$ & $(2,21) * *$ & $(1,65) *$ & $(0,86)$ \\
\hline \multirow[t]{2}{*}{ SURP*SECTORSP (c) } & 0,281 & 0,092 & $-0,001$ & 0,014 & $-0,017$ & $-0,193$ \\
\hline & $(9,42) * * *$ & $(1,42)$ & $(-0,81)$ & $(0,29)$ & $(0,17)$ & $(-1,18)$ \\
\hline \multirow[t]{2}{*}{ BRKSIZE } & & & & 0,390 & 0,459 & 0,34 \\
\hline & & & & $(9,10) * * *$ & $(4,65) * * *$ & $(2,34) * *$ \\
\hline NUMANA & & & & $\begin{array}{l}0,010 \\
(3,80) * * *\end{array}$ & $\begin{array}{l}-0,014 \\
(-2,20) * *\end{array}$ & $\begin{array}{l}-0,019 \\
(-1,95) * *\end{array}$ \\
\hline \multirow[t]{2}{*}{ PAGE } & & & & $-0,019$ & 0,663 & 0,248 \\
\hline & & & & $(-0,14)$ & $(2,08) * *$ & $(0,52)$ \\
\hline \multirow[t]{2}{*}{ FAGE } & & & & 0,413 & $-0,226$ & $-0,159$ \\
\hline & & & & $(3,55) * * *$ & $(-0,93)$ & $(-0,40)$ \\
\hline \multirow[t]{2}{*}{ CAGE } & & & & 0,705 & 2,301 & 0,698 \\
\hline & & & & $(2,00) * *$ & $(3,68) * * *$ & $(0,91)$ \\
\hline \multirow[t]{2}{*}{ TIMELINESS } & & & & $-0,046$ & $-0,118$ & $-0,077$ \\
\hline & & & & $(-2,89) * * *$ & $(-2,76) * * *$ & $(-1,28)$ \\
\hline \multirow[t]{2}{*}{ ASYM } & & & & 0,014 & 0,255 & 0,430 \\
\hline & & & & $(0,29)$ & $(2,29) * *$ & $(2,36) * *$ \\
\hline Observations & 46.656 & 46.637 & 46.184 & 46.654 & 46.635 & 46.182 \\
\hline Adjusted $\mathrm{R}^{2}$ & 0,007 & 0,001 & 0,001 & 0,010 & 0,003 & 0,001 \\
\hline F-test $(b=c)$ & 0,1462 & 0,0330 & 0,0014 & 0,0871 & 0,0563 & 0,0065 \\
\hline
\end{tabular}


Table 6. Institutional, Geographical, and Country Factors

This table reports results relative to the interpretation of the relative superiority of country specialists over sector specialists. All estimations are performed with the whole set of control variables mentioned in previous tables. Specifically, these variables are: BRKSIZE, NUMANA, PAGE, FAGE, CAGE, TIMELINESS and ASYM. Coefficients on these control variables are not reported for space saving considerations but are available from the authors upon request. This table is split into four panels. Panel A recalls the results from table 5 for comparison purposes. Panel B refers to institutional factors. Panel C refers to geographical factors. Panel D refers to country factors. Specifically, the results reported below relate to the following regression models:

$$
\begin{aligned}
\text { CABNRET } T_{\left[t_{0} ; t_{1}\right]} & =\alpha+\beta_{c} \cdot \text { SURP } \cdot \text { COUNTRYSP }+\beta_{s} \cdot \text { SURP } \cdot \text { SECTORSP }+\gamma \cdot \text { Controls }+\varepsilon \\
\text { CABNRET } T_{\left[t_{0} ; t_{1}\right]} & =\alpha+\beta_{c, 1} \cdot \text { SURP } \cdot \text { COUNTRYSP } \cdot \text { FACTOR }+\beta_{c, 2} \cdot \text { SURP } \cdot \text { COUNTRYSP } \cdot(1-\text { FACTOR }) \\
& +\beta_{s} \cdot \operatorname{SURP} \cdot \text { SECTORSP }+\gamma \cdot \text { Controls }+\varepsilon
\end{aligned}
$$

where FACTOR refers to the different variables that are considered as potential explanations of the information advantage of country specialists. Therefore, FACTOR = HACTG, HPROT, HMKTSIZE, LOCAL, DISTANCE, HFACTOR, and HSTD. CABNRET $T_{\left[t_{0} ; t_{1}\right]}$ is the cumulative abnormal return computed over different time windows. The models are successively estimated for $C A B N R E T_{[-1 ;+1]}, C A B N R E T_{[+1 ;+20]}$, and $C A B N R E T_{[+21 ;+60]}$, where the values of $t_{0}$ and $t_{1}$ are expressed in days. SURP is the surprise, or difference, between each newly issued recommendation and the last recommendation previously released by the same analyst on the same firm. The values 1 to 5 are respectively assigned to Strong Buys, Buys, Hold, Sell, and Strong Sell recommendations. $S U R P$ therefore takes discrete values that range from -4 to +4 . COUNTRYSP (SECTORSP) is a dummy variable that is equal to 1 if the recommendation is issued by a country specialist (sector specialist) and 0 otherwise. HACTG (1-HACTG) is a dummy variable that equals 1 if $A C T G$ is above (below) the median and 0 otherwise. HPROT (1-HPROT) is a dummy variable that equals 1 if PROT is above (below) the median and 0 otherwise. HMKTSIZE (1-HMKTSIZE) is a dummy variable that equals 1 if the national market capitalization is above (below) the median and 0 otherwise. $L O C A L$ is a dummy variable that equals 1 if the analyst is located within the same country as the firm for which the forecast is issued. DISTANCE is a dummy variable that equals 1 if the analyst is located less than 100 kilometers away from the firm. HFACTOR is a dummy variable that equals 1 if the recommendation is issued on a firm headquartered in a country with a country factor above the median and 0 otherwise. HSTD is a dummy variable that equals 1 if the country standard deviation is above the median and 0 otherwise. The set of controls variables includes BRKSIZE (a dummy variable that takes the value 1 if the recommendation was issued by an analyst working for a large brokerage house and 0 otherwise), NUMANA (the number of analysts having issued recommendations on the firms over the last 360 days), PAGE (a dummy variable that takes the value 1 if the recommendation 'P'recedes an earnings announcement date by less than 10 days and 0 otherwise), FAGE (a dummy variable that takes the value 1 if the recommendation 'F'ollows an earnings announcement date by less than 10 days and 0 otherwise), CAGE (a dummy variable that takes the value 1 if the recommendation is issued contemporaneously, i.e. on the same day, to an earnings announcement), TIMELINESS (the number or recommendations issued during the previous month on the same firm) and ASYM (a dummy that equals one for upgrades and zero otherwise interacted with the surprise). As the models we estimate include both recommendation upgrades and downgrades, all our controls are multiplied by a variable that takes the value 1 if the recommendation revision is an upgrade, -1 if it is a downgrade, and zero otherwise. We report heteroskedasticity and serial correlation robust t-statistics in parenthesis below their corresponding coefficient. ${ }^{* * *},{ }^{* *}$, and ${ }^{*}$ indicate statistical significance at the $1 \%, 5 \%$ and $10 \%$ levels, respectively. 


\begin{tabular}{|c|c|c|c|c|}
\hline Variables & & $\begin{array}{c}\text { CABNRET } \\
\text { (1) }\end{array}$ & $\begin{array}{c}\text { CABNRET } 20 \\
\text { (2) }\end{array}$ & $\begin{array}{c}\text { CABNRET60 } \\
\text { (3) }\end{array}$ \\
\hline \multicolumn{5}{|l|}{ Panel A: Basis results } \\
\hline \multirow{2}{*}{ SURP*COUNTRYSP } & (b) & 0,076 & 0,129 & 0,112 \\
\hline & & $(2,21) * *$ & $(1,65) *$ & $(0,86)$ \\
\hline \multirow[t]{2}{*}{ SURP*SECTORSP } & (c) & 0,014 & $-0,017$ & $-0,193$ \\
\hline & & $(0,29)$ & $(0,17)$ & $(-1,18)$ \\
\hline Observations & & 46.654 & 46.635 & 46.182 \\
\hline F-test & $\mathrm{b}=\mathrm{c}$ & 0,010 & 0,003 & 0,001 \\
\hline \multicolumn{5}{|l|}{ Panel B: Institutional Factors } \\
\hline \multirow[t]{2}{*}{ SURP*COUNTRYSP (HACTG) } & (b1) & 0,078 & 0,112 & 0,026 \\
\hline & & $(2,13) * *$ & $(1,33)$ & $(0,19)$ \\
\hline \multirow[t]{2}{*}{ SURP*COUNTRYSP (1-HACTG) } & (b2) & 0,074 & 0,152 & 0,295 \\
\hline & & $(1,85) *$ & $(1,71) *$ & $(1,98) * *$ \\
\hline \multirow[t]{2}{*}{ SURP*SECTORSP } & (c) & 0,014 & $-0,018$ & $-0,201$ \\
\hline & & $(0,29)$ & $(-0,18)$ & $(-1,24)$ \\
\hline Observations & & 46.654 & 46.635 & 46.182 \\
\hline F-test & $\mathrm{b} 1=\mathrm{b} 2$ & 0,885 & 0,588 & 0,007 \\
\hline \multirow[t]{2}{*}{ SURP*COUNTRYSP (HPROT) } & (b1) & 0,070 & 0,074 & $-0,002$ \\
\hline & & $(1,92) *$ & $(0,89)$ & $(-0,02)$ \\
\hline \multirow[t]{2}{*}{ SURP*COUNTRYSP (1-HPROT) } & (b2) & 0,085 & 0,211 & 0,280 \\
\hline & & $(2,10) * *$ & $(2,33) * *$ & $(1,84) *$ \\
\hline \multirow[t]{2}{*}{ SURP*SECTORSP } & (c) & 0,013 & $-0,023$ & $-0,205$ \\
\hline & & $(0,27)$ & $(-0,23)$ & $(-1,27)$ \\
\hline Observations & & 46.654 & 46.635 & 46.182 \\
\hline F-test & $\mathrm{b} 1=\mathrm{b} 2$ & 0,662 & 0,069 & 0,019 \\
\hline \multirow[t]{2}{*}{ SURP*COUNTRYSP (HMKTSIZE) } & (b1) & 0,061 & 0,110 & 0,050 \\
\hline & & $(1,72) *$ & $(1,39)$ & $(0,39)$ \\
\hline \multirow[t]{2}{*}{ SURP*COUNTRYSP (1-HMKTSIZE) } & (b2) & 0,154 & 0,222 & 0,421 \\
\hline & & $(2,95) * *$ & $(1,76) *$ & $(1,90) *$ \\
\hline \multirow[t]{2}{*}{ SURP*SECTORSP } & (c) & 0,010 & $-0,022$ & $-0,209$ \\
\hline & & $(0,20)$ & $(-0,21)$ & $(-1,29)$ \\
\hline Observations & & 46.654 & 46.635 & 46.182 \\
\hline F-test & $\mathrm{b} 1=\mathrm{b} 2$ & 0,048 & 0,327 & 0,055 \\
\hline
\end{tabular}


Table 6 (continued)

\begin{tabular}{|c|c|c|c|c|}
\hline Variables & & $\begin{array}{c}\text { CABNRET } \\
\text { (1) }\end{array}$ & $\begin{array}{c}\text { CABNRET20 } \\
\text { (2) }\end{array}$ & $\begin{array}{c}\text { CABNRET60 } \\
\text { (3) }\end{array}$ \\
\hline \multicolumn{5}{|l|}{ Panel C: Geographical Factors } \\
\hline SURP $*$ COUNTRYSP $($ LOCAL $=1)$ & (b1) & $\begin{array}{l}0,073 \\
(1,38)\end{array}$ & $\begin{array}{l}0,187 \\
(1,59)\end{array}$ & $\begin{array}{l}-0,076 \\
(-0,38)\end{array}$ \\
\hline SURP $*$ COUNTRYSP $($ LOCAL $=0)$ & (b2) & $\begin{array}{l}-0,090 \\
(-0,82)\end{array}$ & $\begin{array}{l}0,163 \\
(0,66)\end{array}$ & $\begin{array}{l}0,039 \\
(0,11)\end{array}$ \\
\hline SURP*SECTORSP & (c) & $\begin{array}{l}-0,009 \\
(-0,13)\end{array}$ & $\begin{array}{l}-0,035 \\
(-0,24)\end{array}$ & $\begin{array}{l}-0,480 \\
(-2,06)\end{array}$ \\
\hline $\begin{array}{l}\text { Observations } \\
\text { F-test }\end{array}$ & $\mathrm{b} 1=\mathrm{b} 2$ & $\begin{array}{r}25.065 \\
0,114\end{array}$ & $\begin{array}{r}25.054 \\
0,911\end{array}$ & $\begin{array}{r}24.743 \\
0,735\end{array}$ \\
\hline SURP*COUNTRYSP (DISTANCE $=1$ ) & (b1) & $\begin{array}{l}0,080 \\
(1,36)\end{array}$ & $\begin{array}{l}0,196 \\
(1,49)\end{array}$ & $\begin{array}{l}-0,040 \\
(-0,19)\end{array}$ \\
\hline SURP*COUNTRYSP (DISTANCE $=0$ ) & (b2) & $\begin{array}{l}0,041 \\
(0,66)\end{array}$ & $\begin{array}{l}0,220 \\
(1,58)\end{array}$ & $\begin{array}{l}-0,019 \\
(-0,08)\end{array}$ \\
\hline SURP*SECTORSP & (c) & $\begin{array}{l}-0,035 \\
(-0,47)\end{array}$ & $\begin{array}{l}-0,060 \\
(-0,39)\end{array}$ & $\begin{array}{l}-0,382 \\
(-1,58)\end{array}$ \\
\hline $\begin{array}{l}\text { Observations } \\
\text { F-test }\end{array}$ & $\mathrm{b} 1=\mathrm{b} 2$ & $\begin{array}{r}22.512 \\
0,462\end{array}$ & $\begin{array}{r}22.502 \\
0,839\end{array}$ & $\begin{array}{r}22.301 \\
0,913\end{array}$ \\
\hline \multicolumn{5}{|l|}{ Panel D: Country Factors } \\
\hline SURP*COUNTRYSP $($ HFACTOR=1) & (b1) & $\begin{array}{l}0,084 \\
(1,96) * *\end{array}$ & $\begin{array}{l}0,099 \\
(0,98)\end{array}$ & $\begin{array}{l}0,286 \\
(1,71) *\end{array}$ \\
\hline SURP*COUNTRYSP $($ HFACTOR=0) & (b2) & $\begin{array}{l}0,074 \\
(2,06) * *\end{array}$ & $\begin{array}{l}0,137 \\
(1,70) *\end{array}$ & $\begin{array}{l}0,062 \\
(0,46)\end{array}$ \\
\hline SURP*SECTORSP & (c) & $\begin{array}{l}0,013 \\
(0,28)\end{array}$ & $\begin{array}{l}-0,016 \\
(-0,16)\end{array}$ & $\begin{array}{l}-0,199 \\
(-1,22)\end{array}$ \\
\hline $\begin{array}{l}\text { Observations } \\
\text { F-test }\end{array}$ & $\mathrm{b} 1=\mathrm{b} 2$ & $\begin{array}{r}46.654 \\
0.780\end{array}$ & $\begin{array}{r}46.635 \\
0.655\end{array}$ & $\begin{array}{r}46.182 \\
0.108\end{array}$ \\
\hline SURP*COUNTRYSP $(\mathrm{HSTD}=1)$ & (b1) & $\begin{array}{l}0,114 \\
(2,72) * *\end{array}$ & $\begin{array}{l}0,194 \\
(2,07) * *\end{array}$ & $\begin{array}{l}0,293 \\
(1,83) *\end{array}$ \\
\hline SURP*COUNTRYSP $(\mathrm{HSTD}=0)$ & (b2) & $\begin{array}{l}0,049 \\
(1,37)\end{array}$ & $\begin{array}{l}0,076 \\
(0,93)\end{array}$ & $\begin{array}{l}-0,028 \\
(-0,22)\end{array}$ \\
\hline SURP*SECTORSP & (c) & $\begin{array}{l}0,015 \\
(0,31)\end{array}$ & $\begin{array}{l}-0,023 \\
(-0,22)\end{array}$ & $\begin{array}{l}-0,208 \\
(-1,27)\end{array}$ \\
\hline Observations & & 46.436 & 46.417 & 45.964 \\
\hline F-test & $\mathrm{b} 1=\mathrm{b} 2$ & 0,054 & 0,125 & 0,009 \\
\hline
\end{tabular}

